\title{
A new spatially and temporally variable sigma parameter in degree-day melt modelling of the Greenland Ice Sheet 1870-2013
}

A. E. Jowett ${ }^{1}$, E. Hanna ${ }^{1}$, F. Ng ${ }^{1}$, P. Huybrechts ${ }^{2}$, and I. Janssens ${ }^{2}$

${ }^{1}$ Department of Geography, University of Sheffield, Sheffield, S10 2TN, UK

${ }^{2}$ Earth System Sciences and Departement Geografie, Vrije Universiteit, Brussel, Belgium

Received: 27 August 2015 - Accepted: 4 September 2015 - Published: 5 October 2015

Correspondence to: A. E. Jowett (a.jowett@sheffield.ac.uk)

Published by Copernicus Publications on behalf of the European Geosciences Union.

A new spatially and temporally variable sigma parameter in degree-day melt

A. E. Jowett et al.

\section{Title Page}

$<$ 


\section{Abstract}

The degree-day based method of calculating ice-/snow-melt across the Greenland Ice Sheet (GrIS) commonly includes the temperature parameter sigma $(\sigma)$ accounting for temperature variability on short (sub-monthly down to hourly) timescales, in order to

5 capture melt in months where the mean temperature is below $0^{\circ} \mathrm{C}$. Sigma is typically assumed to be constant in space and time, with values ranging from $\sim 2.5$ to $5.5^{\circ} \mathrm{C}$. It is unclear in many cases how these values were derived and little sensitivity analysis or validation has been conducted. Here we determine spatially and temporally varying monthly values of $\sigma$ for the unique, extended 1870-2013 timescale based on downscaled, corrected European Centre for Medium-Range Weather Forecasts (ECMWF) Interim (ERA-I) and Twentieth Century Reanalysis (20CR) meteorological reanalysis $2 \mathrm{~m}$ air temperatures on a $5 \mathrm{~km} \times 5 \mathrm{~km}$ polar stereographic grid for the GrIS. The resulting monthly $\sigma$ values reveal a distinct seasonal cycle. The mean summer $\sigma$ value for the study period is $\sim 3.2^{\circ} \mathrm{C}$, around $1{ }^{\circ} \mathrm{C}$ lower than the value of $4.2^{\circ} \mathrm{C}$ commonly used in the literature. Sigma values for individual summers range from 1.7 to $5.9^{\circ} \mathrm{C}$. Since the summer months dominate the melt calculation, use of the new variable $\sigma$ parameter would lead to a smaller melt area and a more positive surface mass balance for the GrIS. Validation of our new variable $\sigma$ dataset shows good agreement with standard deviations calculated from automatic weather station observations across the ice sheet. Trend analysis shows large areas of the ice sheet exhibit statistically significant increasing temperature variability from 1870-2013 in all seasons, with notable exceptions around Summit in spring, and Summit and South Dome in winter. More recently, since 1990, $\sigma$ has been decreasing, significantly so in the north-west during July. These interannual $\sigma$ trends reflect climate change and variability processes operating across
A new spatially and temporally variable sigma parameter in degree-day melt

A. E. Jowett et al.

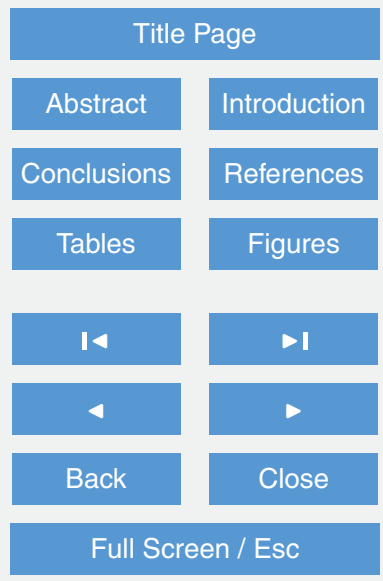

Printer-friendly Version

Interactive Discussion 


\section{Introduction}

The temperature index melt method exploits the empirical relationship between nearsurface air temperature and ablation rate through the calculation of positive degree days (PDDs) (Hock, 2003). Within the PDD calculation, the sigma $(\sigma)$ parameter is 5 used in the following equation to account for temperature variations due to the diurnal temperature cycle and random weather fluctuations:

$\sigma=\sqrt{\frac{1}{N} \sum_{i=1}^{N}\left(T_{i}-T_{\mathrm{m}}\right)^{2}}$

where $N$ is the number of temperature observations, $T_{i}$ is temperature and $T_{\mathrm{m}}$ is the mean temperature. These temperature fluctuations lead to short-term positive excur${ }_{0}$ sions that cause melt during months when the average temperature is below $0{ }^{\circ} \mathrm{C}$; therefore $\sigma$ allows the model to capture melt during these months. Assuming a normal distribution of the fluctuations around $T_{\mathrm{m}}$, for $\Delta t$ days we have PDD $=\Delta t \times \mathrm{EPD}$, where EPD is the expected positive degree given be Eq. (2):

$\mathrm{EPD}=\frac{1}{\sigma \sqrt{2 \pi}} \int_{0}^{\infty} T \exp \left[-\frac{\left(T-T_{\mathrm{m}}\right)^{2}}{2 \sigma^{2}}\right] \mathrm{d} T$

15 or (after evaluating the integral)

$\mathrm{EPD}=\sigma \beta\left(\frac{T_{\mathrm{m}}}{\sigma}\right)=\sigma\left[\frac{T_{\mathrm{m}}}{\sigma} \phi\left(\frac{T_{\mathrm{m}}}{\sigma}\right)+f\left(\frac{T_{\mathrm{m}}}{\sigma}\right)\right]$

(Huybrechts and de Wolde, 1999; Janssens and Huybrechts, 2000). Here, the function $\beta$ involves the standard normal distribution function $\varphi$ and the standard normal density function $f$.The PDD in a year having the monthly mean temperatures $T_{\mathrm{m}}$ and constant $\sigma$ is then

A new spatially and temporally variable sigma parameter in degree-day melt

A. E. Jowett et al.

Title Page

Abstract Introduction

Conclusions

Tables References Figures

14

4

Back

Close

Printer-friendly Version

Interactive Discussion 
$\mathrm{PPD}=\sigma \int^{\text {YEAR }} \beta\left(\frac{T_{\mathrm{m}}}{\sigma}\right) \mathrm{d} t$.

Equations (1) and (4) allow efficient computation of melt in ice-sheet models by parameterising the effect of diurnal temperature fluctuations and circumventing the need to resolve them. In this paper, we refer to them as the PDD parameterisation, and $\sigma$ as 5 the temperature-variability parameter.

Numerous GrIS simulations had assumed a constant $\sigma$ between $\sim 2.5$ and $5.5^{\circ} \mathrm{C}$ (e.g. Fausto et al., 2009a; Reeh, 1991; Ritz et al., 1997; Huybrechts and de Wolde, 1999; Janssens and Huybrechts, 2000), with $4.2^{\circ} \mathrm{C}$ being a typical value (Janssens and Huybrechts, 2000; Hanna et al., 2011). Recently, however, it is realised that the choice of $\sigma$ can significantly affect melt model output, and that capturing the spatiotemporal variations of $\sigma$, notably for the summer months, may improve estimated of GrIS melt (e.g. Lefebre et al., 2002; Fausto et al., 2009a, b). This is even though the PDD method is an empirical index method based on temperature, but in reality surface melt is a function of energy fluxes at the surface (net long wave, net shortwave, turbulent heat fluxes) and these fluxes are not a direct function of surface temperature. The PDD is a quick-and-easy method that is not physically based, but works well when compared to physically-based methods (and is elegant to use as it only has three parameters) (Braithwaite, 1995).

For instance, a sensitivity analysis carried out by Fausto et al. (2009a) showed a $33 \%$ 20 increase in the modelled melt area over the GrIS when using a summer $\sigma$ value of $4.5^{\circ} \mathrm{C}$ instead of $2.53^{\circ} \mathrm{C}$. As an increased summer $\sigma$ indicates more excursions above $0^{\circ} \mathrm{C}$ for any given area on the ice sheet, more melt occurs in areas already experiencing melt - in addition to expanding the melt area. Fausto et al. (2009a) derived their lower $\sigma$ estimate from Eq. (1) based on observed monthly $2 \mathrm{~m}$ air temperatures from 1996 to 2006. Similarly, Lefebre et al. (2002) derived July $\sigma$ values of 2 to $3^{\circ} \mathrm{C}$ based on $2 \mathrm{~m}$ air temperatures from the European Centre for Medium-Range Weather Forecasts (ECMWF) re-analysis at the $20 \mathrm{~km}$ grid scale for the year 1991. Lefebre et al. (2002)'s

A new spatially and temporally variable sigma parameter in degree-day melt

A. E. Jowett et al.

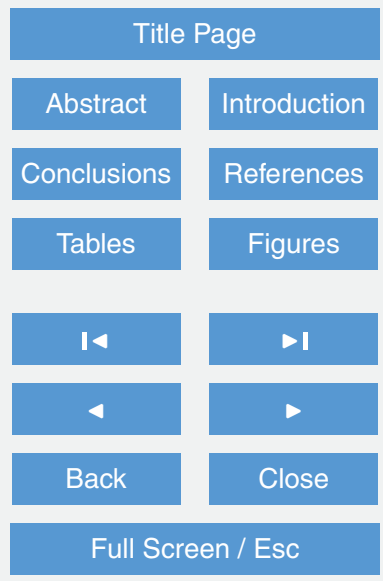

Printer-friendly Version

Interactive Discussion 
results further support the findings of Fausto et al. (2009a), that $\sigma$ varies spatially and temporally across the GrIS due to the large variations in meteorological and climatic conditions experienced across the ice sheet (Lefebre et al., 2002; Cappelen et al., 2014). It follows that the approach of using a constant $\sigma$ in the temperature-index pa5 rameterisation may be invalid, and that introducing spatial and or temporal variations in $\sigma$ (e.g. as explored by Fausto et al., 2009a and Lefebre et al., 2002) is fundamentally a better approach.

Consequently, several recent studies have attempted to derive variable $\sigma$ parameter sets from both automatic weather station (AWS) temperature records and reanalysis temperature products. Fausto et al. (2009b) used Eq. (1) and AWS data from the GrIS to calculate the least squares fit of summer $\sigma$ from 1996 to 2006 in an observationbased parameterisation. There is a large altitudinal component to the distribution of $\sigma$, with values of around $5^{\circ} \mathrm{C}$ in the highest elevation regions but only around $2{ }^{\circ} \mathrm{C}$ near the periphery of the ice sheet (Fausto et al., 2009b). The authors also identified an annual cycle in $\sigma$, with $\sigma$ values larger in the winter months and smaller during summer (Fausto et al., 2009b; Lefebre et al., 2002). The low summer values were largely attributed to the limiting effects of melt on surface temperatures and therefore near-surface air temperatures during the melt season, which is absent during other months (Fasuto et al., 2009b). There is also a larger scatter in $\sigma$ calculated at lower elevations, which Fausto et al. (2009b) attributed to higher vulnerability to atmospheric variability of the AWS sites located near the coast.

The validation results of Fausto et al. (2009b) show that $\sigma$ is within $1{ }^{\circ} \mathrm{C}$ of the observations at AWS sites, and increasing accuracy with elevation. Despite this agreement, Fausto et al. (2009b) suggest that using just the mean summer $\sigma$ is not sufficient to model annual ablation. Including an annual $\sigma$ distribution more realistically depicts real temperature variability; however, Fausto et al. (2009b) stated that the calculation of an "annual distributed cycle" in temperature variations was limited by data availability.

Several more recent studies have sought to address this data availability issue using re-analysis products to calculate $\sigma$ grids for the GrIS. Sequinot (2013) used ECMWF
A new spatially and temporally variable sigma parameter in degree-day melt

A. E. Jowett et al.

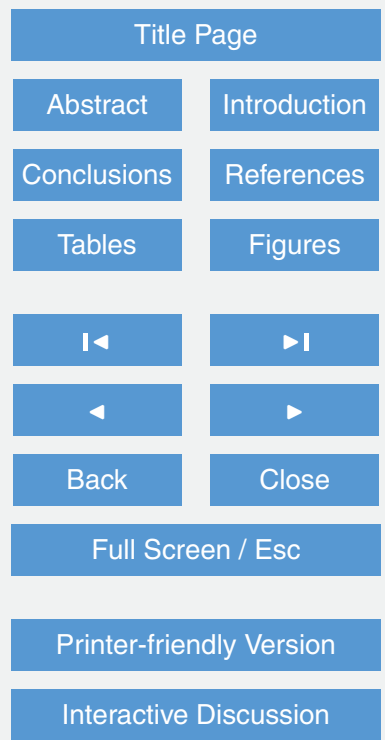


Interim (ERA-I) reanalysis from 1979 to 2012 in Eq. (1) to derive global monthly $\sigma$ grids; however, daily temperature averages were taken before calculating $\sigma$ so the resulting parameter does not appear to capture variability due to the diurnal cycle. The resulting $\sigma$ values range from 0.32 to $12.63^{\circ} \mathrm{C}$ globally, and are generally higher in the 5 winter and lower in the summer (Seguinot, 2013). Rogozhina and Rau (2014) used ECMWF ERA-40 reanalysis from 1958 to 2001 to produce a $10 \mathrm{~km} \times 10 \mathrm{~km} \sigma$ gridded dataset for the GrIS. The resulting monthly $\sigma$ fields show seasonal cycles, with higher values in the winter and lower values of $1.1-2^{\circ} \mathrm{C}$ in summer (July) (Rogozhina and Rau, 2014). Again, $\sigma$ is higher in the centre of the ice sheet and decreases towards 10 the margin (Rogozhina and Rau, 2014). Seguinot and Rogozhina (2014) further developed this work, by producing long-term $\sigma$ fields for application to multimillennial ice sheet surface mass balance (SMB) modelling. Finally, Wake and Marshall (2015) used Greenland Climate Network (GC-Net) data to determine that the quadratic function of mean monthly temperature is a better representation of $\sigma$ than a constant parameter. Our study presents a further advance in this field, by providing $\sigma$ results on the higher resolution $5 \mathrm{~km} \times 5 \mathrm{~km}$ grid, using a combination of ERA-I and Twentieth Century Reanalysis (20CR) reanalysis to extend the time period from 1870 to 2013 and providing a comprehensive validation of our results using AWS data for various time periods. Furthermore, trends in $\sigma$ over time are discussed here, which, to our knowledge at the time of submission, has not been carried out before.

Given the range of currently-assumed $\sigma$ values in the literature, the potential difference this has on melt area and therefore SMB, together with the findings of studies like Rogozhina and Rau (2014) where SMB was found to be highly sensitive to $\sigma$, it is clearly vital to better constrain this parameter. As a result, this study presents an alternative optimised $\sigma$ parameter based on calculations using downscaled, corrected ERA-I and 20CR meteorological reanalysis $2 \mathrm{~m}$ air temperatures on a $5 \mathrm{~km} \times 5 \mathrm{~km}$ polar stereographic grid for the GrIS from 1870-2013 inclusive (Compo et al., 2011; Dee et al., 2011). This is achieved through modification of the Janssens and Huybrechts (2000) temperature index melt model, to incorporate monthly varying $\sigma$ values in the
A new spatially and temporally variable sigma parameter in degree-day melt

A. E. Jowett et al.

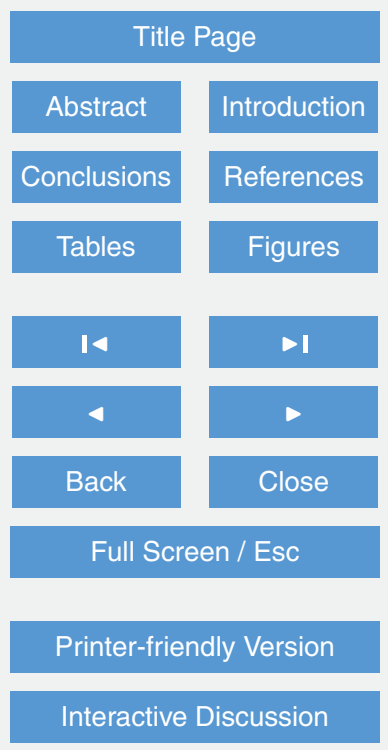


calculation of melt within the degree-day calculation. The following two sections discuss our method of calculating the new $\sigma$ parameter (Sect. 2) and characteristics of the resulting monthly-varying $\sigma$ (Sect. 3). Section 4 discusses the validation and application of this new parameter, including a discussion of recent temperature variability over the 5 GrIS. The effect of our new $\sigma$ parameter on the SMB and component outputs from the modified version of the temperature index melt model will be discussed in a separate paper.

\section{Datasets and methods}

\subsection{Pre-processing of temperature data and calculation of $\sigma$}

10 For this study, the freely-available gridded $2 \mathrm{~m}$ air temperature data from ECMWF ERAI reanalysis (Dee et al., 2011) spanning 1979-2013 and 20CR meteorological reanalysis version 2 (Compo et al., 2011) spanning 1870-2008 were acquired and subsets extracted covering the Greenland area. These temperatures were then downscaled by a process of bilinear interpolation from the $2^{\circ} \times 2^{\circ}$ latitude/longitude grid (20CR) and $1580 \mathrm{~km} \times 80 \mathrm{~km}(\mathrm{ERA}-\mathrm{I})$ to a $5 \mathrm{~km} \times 5 \mathrm{~km}$ polar stereographic grid. A topographic correction was applied to these downscaled $2 \mathrm{~m}$ air temperatures to remove errors associated with differences in orography between the original coarse-resolution reanalysis data and the $5 \mathrm{~km} \times 5 \mathrm{~km}$ grid, following the method of Hanna et al. (2011) that is based on the ice sheet surface DEM of Ekholm (1996). The reanalysis data are available at 6 hourly timesteps for the ERA-I and 3 hourly timesteps for the 20CR.

In order to generate a continuous $\sigma$ series from 1870-2013 inclusive, some preprocessing of the $2 \mathrm{~m}$ air temperatures from both the 20CR and ERA-I was required to merge the two datasets. Following the method of Hanna et al. (2011), the mean monthly difference between the 20CR and ERA-I temperatures were calculated and then added onto the 20CR temperatures as a systematic correction, which did not change the variability in the $20 \mathrm{CR}$ but scaled the $20 \mathrm{CR} 2 \mathrm{~m}$ air temperatures to ERA-
A new spatially and temporally variable sigma parameter in degree-day melt

A. E. Jowett et al.

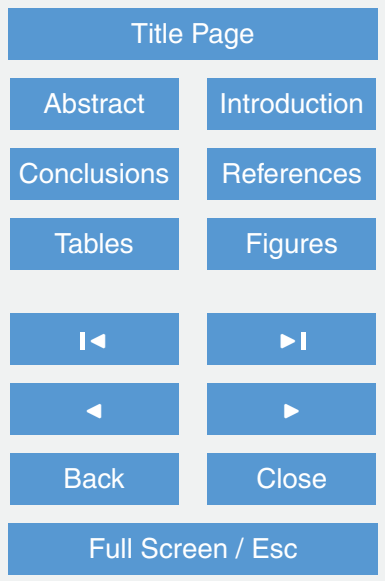

Printer-friendly Version

Interactive Discussion 
I, correcting for the systematic low-temperature bias when compared to ERA-I (see Fig. 2).

Ferguson and Villarini $(2012,2014)$ detected the presence of inhomogeneities in 20CR surface air temperature causing step changes in temperature and precipitation 5 between 1940 and 1950 over the United States. These inhomogeneities or breakpoints occur due to factors including an increase in the number of observations used in the reanalysis around this time (Ferguson and Villarini, 2012). The authors noted that these inhomogeneities may vary regionally. We therefore identified and corrected for such inhomogeneities or artificial breakpoints in our 20CR $2 \mathrm{~m}$ air temperature. 10 Breakpoint analysis was carried out on the systematically corrected temperature series using the Bai-Perron structural change point test in $\mathrm{R}$ version 3.1.1 (Ferguson and Villarini, 2014). The Bai-Perron analysis was first carried out on monthly time series of downscaled, corrected 20CR $2 \mathrm{~m}$ air temperatures for each month in turn, to identify any breaks in temperature. The uncertainty estimates for $2 \mathrm{~m}$ air temperatures 15 (ensemble spread) were then analysed in the same way. The breakpoints and their $95 \%$ confidence intervals were identified in the $2 \mathrm{~m}$ air temperature and the spread data and compared to determine the cause of any breaks. If the $95 \%$ confidence intervals in both datasets overlap then the cause is determined to be non-climatological and interpreted to be an artificial break in the data that needs correcting, whereas if the respective breakpoint confidence intervals do not overlap the cause is considered climatological (Ferguson and Villarini, 2014). To correct for any artificial breakpoints, the mean $2 \mathrm{~m}$ air temperature was calculated for the periods both before and after the breakpoint. The difference between the two means was then added to each year as an inhomogeneity correction in the period before the artificial breakpoint, thus bringing the $2 \mathrm{~m}$ air temperatures of the period before the break in line with those afterwards, removing the artificial step change in temperature.

The complete corrected monthly temperature series and 6 hourly (3 hourly) ERA-I (20CR) temperatures were input into Eq. (1) to calculate new $\sigma$ values. This gave a new spatially and temporally varying $5 \mathrm{~km} \times 5 \mathrm{~km}$ gridded monthly $\sigma$ series from 1870-2013

A new spatially and temporally variable sigma parameter in degree-day melt

A. E. Jowett et al.

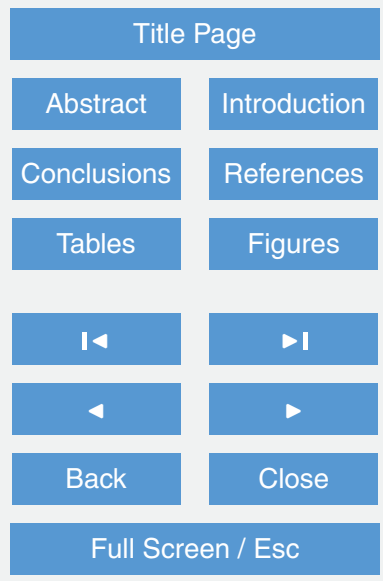

Printer-friendly Version

Interactive Discussion 
inclusive. These new $\sigma$ values provide a more sophisticated and realistic alternative to the conceptually simpler constant $\sigma$ value, and were interactively fed into the PDD model in Eq. (4).

\subsection{Validation of the variable $\sigma$ parameter}

5 In order to investigate how much of an improvement our new temperature variability parameter presents over the constant $\sigma$ approach, correlation analysis was carried out. The $\sigma$ fields were correlated with those derived from $2 \mathrm{~m}$ air temperature observations of the Danish Meteorological Institute (DMI), GC-Net and Programme for Monitoring of the Greenland Ice Sheet (PROMICE) AWS (Fig. 1), for the time period of available observations at each station (Cappelen et al., 2013; Steffen et al., 1996; Ahlstrøm et al., 2008). The statistical significance of the relationship was used to determine if our new $\sigma$ values sufficiently capture observed temperature variability, with the $95 \%$ threshold applied as a minimum value for statistical significance. Only stations where the record was two thirds complete were used in the validation.

15 To detect how temperature variability has changed and therefore any potential climate change signals in $\sigma$ from 1870-2013, trend analysis was carried out at annual, seasonal and monthly timescales. Linear least squares regression for these timescales was conducted for each grid cell to calculate the rate of change per year from 18702013 and for the 1990-2013 sub-period of recent strong Arctic amplification (Overland et al., 2014). Standard climatological seasons were used: i.e. spring = March, April, May; summer = June, July, August; autumn = September, October, November; winter $=$ December, January, February. The significance of regional trends was assessed by calculating the $p$ value based on the correlation coefficient of all successive $\sigma$ values for that grid cell plotted against time and the degrees of freedom (number of time-steps 25 minus two). A $p$ value of 0.05 is defined as the threshold for statistical significance in line with the $95 \%$ significance level used throughout.

\section{A new spatially and temporally variable sigma parameter in degree-day melt \\ A. E. Jowett et al.}

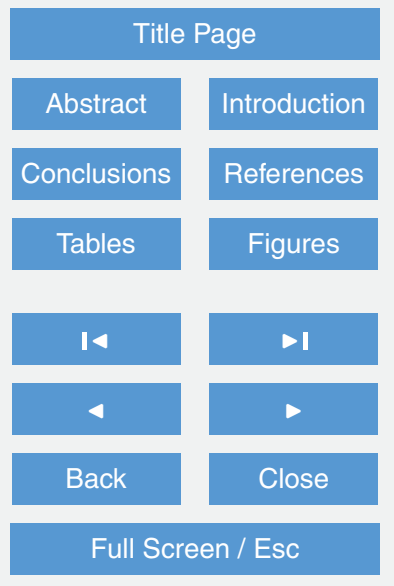

Printer-friendly Version

Interactive Discussion 


\section{Results}

\subsection{Effect of applying corrections on $\sigma$ time series}

Figure 2 graphically plots the $2 \mathrm{~m}$ air temperature series, spread data, their breakpoints and confidence intervals, clearly showing that the artificial jumps in the $2 \mathrm{~m}$ air temper-

5 ature series are due to model artefacts. Table 1 quantifies these inhomogeneities by showing the year of the break in each monthly series and the correction factor to be applied. The breakpoint analysis detected breaks in five out of the twelve months. Of these five months, only one break was detected in the $2 \mathrm{~m}$ air temperatures, each having a corresponding break in the spread series for which the confidence intervals overlap. These breakpoints are therefore considered a product of the modelling process and the 20CR $2 \mathrm{~m}$ temperature time series were adjusted for them using the correction factors in Table 1. This altered the mean temperatures for the time periods before the breakpoints in the respective time series, as shown in Fig. 3.

Overall, applying the different correction stages to 20CR $2 \mathrm{~m}$ air temperatures brings them into closer agreement with the ERA-I $2 \mathrm{~m}$ air temperatures for the overlap period 1979-2008 for all plots shown in Fig. 3. The ice sheet average temperature difference between 20CR and ERA-I before the correction process was $0.59^{\circ} \mathrm{C}$ compared to $0.05{ }^{\circ} \mathrm{C}$ thereafter for the annual data. The residual difference is likely due to the correction process taking the mean difference in 20CR and ERA-I for the whole period 1979-2008, and applying this to monthly $2 \mathrm{~m}$ air temperature. Scaling the 20CR to ERA-I downscaled and corrected $2 \mathrm{~m}$ air temperatures increases the temperature by an average of $0.6^{\circ} \mathrm{C}$ for annual, $0.3^{\circ} \mathrm{C}$ in spring, $1.4^{\circ} \mathrm{C}$ in summer, $1.1^{\circ} \mathrm{C}$ in autumn and by $1.5^{\circ} \mathrm{C}$ in July. Winter is the only season where scaling to ERA-I reduces the temperature by an average of $0.4^{\circ} \mathrm{C}$ (Fig. 3e). Correcting these scaled 20CR $2 \mathrm{~m}$

air temperatures for breakpoints reduces the temperatures again for the early part of

the record before the breakpoints in Table 1 by $0.4^{\circ} \mathrm{C}$ at the annual scale, $0.7^{\circ} \mathrm{C}$ in spring, $0.1^{\circ} \mathrm{C}$ in summer, $0.5^{\circ} \mathrm{C}$ in autumn and $0.1^{\circ} \mathrm{C}$ in winter on average from 1870 2008. The period after the breakpoints remains unchanged from the scaled series in all

A new spatially and temporally variable sigma parameter in degree-day melt

A. E. Jowett et al.

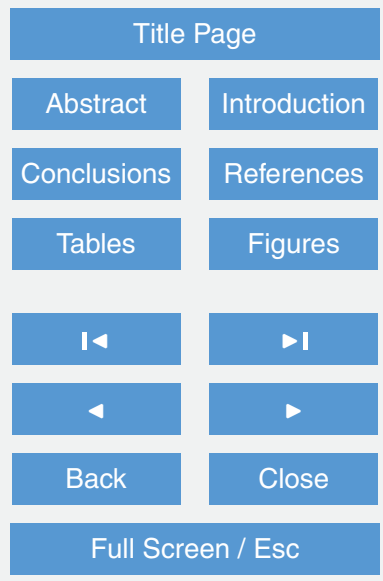

Printer-friendly Version

Interactive Discussion 
months where breaks were detected in Table 1. Figure 3a shows that there is still some disagreement with ERA-I for the overlap period, particularly in the early to mid-2000s.

Figure $3 b$ shows that for spring, the period before breakpoints were detected in the 1940 s has the largest difference between the corrected and breakpoints series. From 5 the early 1940s there is good agreement between all stages of the correction process with small changes at each step. The breakpoints series is in close agreement with ERA-I with a mean difference of $0.0004^{\circ} \mathrm{C}$ for the overlap period. The largest discrepancies between corrected 20CR and the breakpoints series are shown in Fig. 3c during the summer, particularly in the early part of the record. The corrected 20CR series are $\sim 1-1.5^{\circ} \mathrm{C}$ lower than the breakpoint series. There is however, good agreement between the breakpoints series and ERA-I for the overlap period with an average difference of $0.0002^{\circ} \mathrm{C}$. The different correction stages show less disagreement for autumn (Fig. 3d) with again good agreement between the breakpoint series and ERA-I series with an average difference of $-0.0004^{\circ} \mathrm{C}$ for the overlap period. No breakpoints were detected in any of the winter months (DJF), so the final stage of correction here was scaling to ERA-I $2 \mathrm{~m}$ air temperatures. The two $20 \mathrm{CR}$ series show good agreement throughout (mean difference of $0.38^{\circ} \mathrm{C}$ from 1870-2008) and with ERA-I (mean difference $0.03^{\circ} \mathrm{C}$ between scaled and ERA-I from 1979-2008). Similarly the July series has no breakpoints, with only August out of the summer months contributing to the breakpoints correction in Fig. 3c. The scaled series is therefore the final stage of the correction for July and shows much better agreement with ERA-I with a mean difference of $0^{\circ} \mathrm{C}$ from 1979-2008, although there are clear differences between scaled 20CR and ERA-I for the overlap period, most notably the systematic bias in 1982, 1983, 1999, 2002 and 2004, when the difference between the series exceeded $\pm 1^{\circ} \mathrm{C}$.

The resulting spliced $2 \mathrm{~m}$ air temperature series, shown in Fig. 4, takes 20CR from $1870-1978$, i.e. to the beginning of the ERA-I record together with the full available ERA-I series from 1979-2013. There is a clear narrowing of the difference between the spliced and unspliced series through time from $0.56^{\circ} \mathrm{C}$ in 1870 to $0.46^{\circ} \mathrm{C}$ in 2008 ,

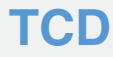

9, 5327-5371, 2015

A new spatially and temporally variable sigma parameter in degree-day melt

A. E. Jowett et al.

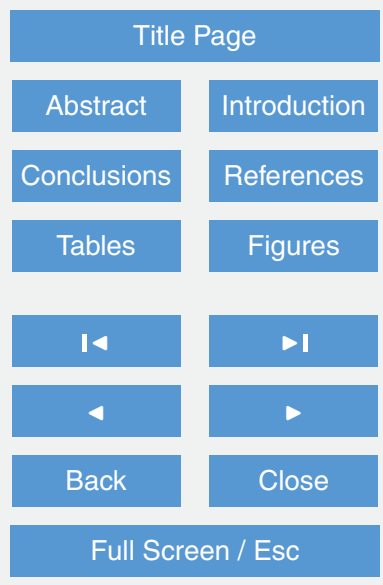

Printer-friendly Version

Interactive Discussion 
with the gap closing completely in the 1960s, after the last breakpoint in 1966 (Table 1), then a slight widening again after 1979 when the ERA-I is introduced.

\subsection{Spatio-temporal variation in $\sigma$}

Figure 5 shows an overall increase in $\sigma$ from 1870-2013 for all seasons, annual and July plots, with relatively low $\sigma$ until the 1930s, followed by a period of increasing $\sigma$ until the 1960s, then a slight decrease to the 1980s plateauing since then but little apparent overall change, particularly in summer and July. Before the 1930s, annual, spring, autumn and winter $\sigma$ all appear to fluctuate around or close to the assumed value of $4.2^{\circ} \mathrm{C}$. Since $1930, \sigma$ increased in these series to between 5 and $7^{\circ} \mathrm{C}$. The summer and July plots in Fig. 5 show that $\sigma$ was lower than $4.2^{\circ} \mathrm{C}$ pre-1930, rising to just below $4.2^{\circ} \mathrm{C}$ from the 1940 s before falling again in the 1980 s to between 2.5 and $3.5^{\circ} \mathrm{C}$, with an ice sheet average $\sigma$ of $\sim 3.2^{\circ} \mathrm{C}$ for the whole study period in summer.

In Fig. 6 the annual, seasonal and July mean $\sigma$ plots show that $\sigma$ increases with elevation, reaching up to $10^{\circ} \mathrm{C}$ around Summit (above $3000 \mathrm{~m}$ elevation) in winter. The range of $\sigma$ values varies between seasons and individual months. During summer, lower values from $1{ }^{\circ} \mathrm{C}$ at the periphery to $6^{\circ} \mathrm{C}$ in the middle of the ice sheet dominate, showing areas where $\sigma$ is currently under- and over-estimated by the constant- $\sigma$ parameter. July shows the same range but with lower values extending further into the ice sheet to around $2000 \mathrm{~m}$ elevation, as opposed to $1500 \mathrm{~m}$ for summer. During spring and autumn, $\sigma$ ranges from 1 to $9^{\circ} \mathrm{C}$, again with higher values at elevations above $2000 \mathrm{~m}$.

Figure 7 shows that when spatial variations are averaged out a clear seasonal cycle in $\sigma$ emerges, with lower mean values in the summer months $\left(2.6^{\circ} \mathrm{C}\right.$ for July), as discussed above, and higher mean values in the winter $\left(5.9^{\circ} \mathrm{C}\right.$ for January). The interquartile ranges show that over $50 \%$ of the data lie within \pm 2 standard deviations of the monthly mean, with only one point in June falling outside the error bars for summer. The rest of the data fall within the monthly maximum and minimum lines, showing the presence of relatively high and low outliers in all months except July and August. Dur-

A new spatially and temporally variable sigma parameter in degree-day melt

A. E. Jowett et al.

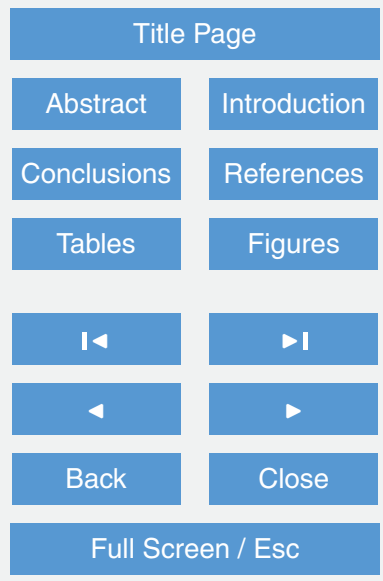

Printer-friendly Version

Interactive Discussion 
ing June and July the interquartile ranges are narrower, indicating less variability about the mean during these months.

\section{3 $\sigma$ validation}

The comparison of modelled ( $\sigma$ calculated from ERA-I and 20CR) and observed (cal5 culated from observed AWS 2 m-air temperature) $\sigma$ in Fig. 8 shows the strongest correlation with the annual data, which is a highly significant $(p<0.01)$ positive relationship between the observations and modelled $\sigma$ when averaged over the year. Despite being weaker, the summer and July correlations are still highly significant $(p<0.01)$ positive relationships between the observed and modelled $\sigma$. Overall there is statistically significant agreement between the observed and modelled $\sigma$ calculated from reanalysis data to those data points on the ice sheet for the periods where validation data are available.

There is a systematic bias in the sign of the offset between observed and modelled $\sigma$ when plotted against elevation (Fig. 9). The new modelled $\sigma$ parameter overestimates the observed $\sigma$ in the ablation zone below the equilibrium line altitude (ELA), which lies at $\sim 1500 \mathrm{~m}$. There is a shift in the sign of the difference in the accumulation zone where the model parameter underestimates $\sigma$ compared to the observations. The annual, summer and July correlations in Fig. 9 indicate highly significant negative relationships, with $\sigma$ decreasing with elevation.

20 Figure 10 shows weak negative correlations between the difference in observed and modelled $\sigma$, and latitude. Despite these correlations being relatively weak compared with those in Fig. 9, the $\mathrm{R}$ values indicate all three correlations are highly significant: annual and summer at the $99 \%$ level and July at the $95 \%$ level: this is due to the large number of data points (pixels) on the ice sheet. The trend lines indicate the bias shifts further northwards, with positive differences in the south between 60 and $65^{\circ} \mathrm{N}$, shifting to more negative differences further north. This indicates that the new parameter underestimates $\sigma$ by $0.06(0.82)^{\circ} \mathrm{C}$ in the south (north) on average. There is however,

A new spatially and temporally variable sigma parameter in degree-day melt

A. E. Jowett et al.

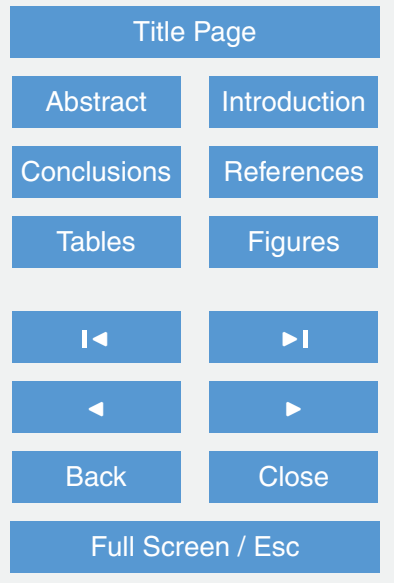

Printer-friendly Version

Interactive Discussion 
considerable scatter around the trend lines; therefore this effect is hard to compensate for by further correcting the $\sigma$ data.

\subsection{Trends in $\sigma$}

All trends in Fig. 11 are positive from 1870-2013, implying that temperature has be5 come more variable over the study period. The largest trends in $\sigma$ are in the southern and north-western parts of the ice sheet, indicating that temperature has become relatively more variable over time here than anywhere else. The smallest rates of change in $\sigma$ are consistently found at high elevations in the centre of the ice sheet. This area displays trends ranging from $0.0-0.3^{\circ} \mathrm{C}$ decade $^{-1}$, equivalent to an increased temperature variability of $\sim 0.0-4.3^{\circ} \mathrm{C}$ over the whole 144 year period. $\sigma$ is therefore still becoming more variable in the centre but less so than in more peripheral regions. The centre of the ice sheet is also the only region which shows non-statistically significant results for spring and winter, indicating that these weaker trends could occur by chance. In Fig. 11a the annual rate of change in $\sigma$ for each $5 \mathrm{~km} \times 5 \mathrm{~km}$ grid cell is positive from cates that all $p$ values lie between 0 and 0.006 , so we interpret these long-term trends in annual $\sigma$ to be statistically significant.

The spring plots show a similar spatial pattern in trend to the annual plot, with smaller values around Summit at higher elevations of the ice sheet. The range in values is greater, from $\sim 0.7^{\circ} \mathrm{C}$ in the centre to $\sim 5.8^{\circ} \mathrm{C}$ in the north-west periphery of the ice sheet over the whole 144 year period. There is an area around Summit in the centre of the ice sheet where these trends are not significant: $p$ values exceed 0.05 here, indicated by blue, purple and black tones. The rest of the ice sheet shows the trends are statistically significant. The summer trends in Fig. $11 \mathrm{~g}$ show lower values for the ice sheet as a whole than spring or annual trends. The lowest values are on the west coast and the highest in the south and north-west, indicating areas of weaker and stronger trends respectively, but all are statistically significant (Fig. 11h). Autumn $\sigma$ trends range from $\sim 0.7^{\circ} \mathrm{C}$ on the eastern periphery to $\sim 6.5^{\circ} \mathrm{C}$ in the north-west over the 144 year

A new spatially and temporally variable sigma parameter in degree-day melt

A. E. Jowett et al.

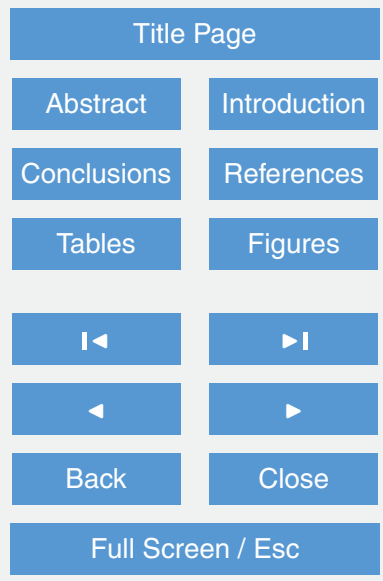

Printer-friendly Version

Interactive Discussion 
period. The $p$ values range from 0 to 0.005 making these trends statistically significant across the ice sheet. The winter trends have the same range as autumn but a different spatial pattern. The lowest values are again in the centre of the ice sheet at the highest elevations, with high values of $\sim 7.2^{\circ} \mathrm{C}$ in the south-west and up to $\sim 6.5^{\circ} \mathrm{C}$ in the 5 north-west over the 144 year period. The trends in the centre of the ice sheet are not significant at the $95 \%$ level with $p$ values over 0.05 in blues and purples, and in excess of 0.09 in black.

Some negative trends are evident over the shorter period 1990-2013 (Fig. 12) and they show greater spatial variation than for the full time series. They are strongest in the 10 south for the annual time series with values of $-0.4^{\circ} \mathrm{C}$ decade ${ }^{-1}$ and in the northwest in July with values down to $-0.3^{\circ} \mathrm{C}$ decade ${ }^{-1}$. Strong positive trends of $0.4^{\circ} \mathrm{C}$ decade $^{-1}$ are apparent in the north at the annual timescale and during the summer (Fig. 12a and b), as well as in the south at higher elevations in July (Fig. 12c). The trend plots show small areas of statistically significant positive trends in the southern region at the 15 annual scale and in the northwest in July.

\section{Discussion}

We first consider the improvements made by the pre-processing of the $20 \mathrm{CR} 2 \mathrm{~m}$ air temperature series. The three step correction process of the original $20 \mathrm{CR} 2 \mathrm{~m}$ air temperature series in spring and winter shows that the uncorrected $20 \mathrm{CR}$ series appears to be biased towards higher temperatures, systematically overestimating temperatures relative to ERA-I. Conversely in summer and autumn, the inverse occurs, where 20CR is biased towards lower temperatures. These $20 \mathrm{CR}$ temperature biases would result in, respectively, over- and under-estimated melt in the PDD-based melt-model calculation. As the process of correcting the 20CR temperature time series does not alter the variation within the dataset, the standard deviation of temperature is not affected and therefore is not deemed essential for the derivation of the new $\sigma$ parameter. However, while the correction would not affect the $\sigma$ calculation, both the 3 hourly and monthly
A new spatially and temporally variable sigma parameter in degree-day melt

A. E. Jowett et al.

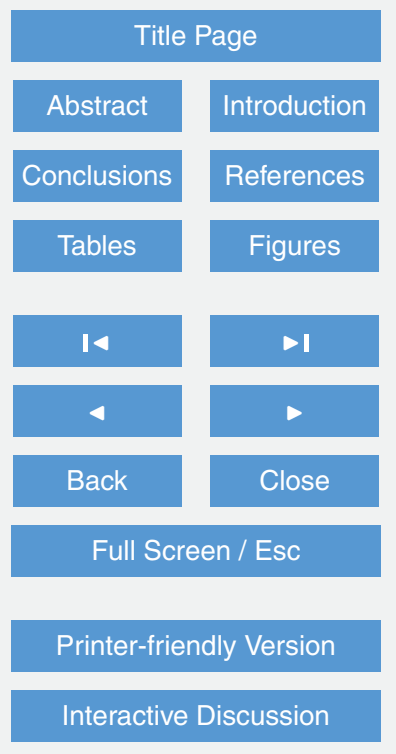


$2 \mathrm{~m}$ air temperatures are fed into the degree-day model for calculating SMB, and are thus essential for better quantifying mass balance. Although the correction process brings 20CR temperatures more in line with ERA-I for the overlap period, there are some discrepancies in absolute values between the fully corrected 20CR and ERA-I 5 series. This suggests that the fully corrected 20CR series in Fig. 3 still does not capture all of the $2 \mathrm{~m}$ air temperature variation and underestimates (overestimates) temperatures in 92 (88) out of 180 cases compared to ERA-I. It is unclear why such a large difference of over $\pm 1{ }^{\circ} \mathrm{C}$ between 20CR and ERA-I occurs in some years, but this could partly be due to the aftermath of climatically-significant volcanic eruptions, e.g. in 1982 10 and 1983 where 20CR over or under-estimates the volcanic effect on Greenland temperatures compared to ERA-I. The ERA-I reanalysis is assumed to be more accurate than 20CR as the reanalysis product is more sophisticated/higher-resolution and involves the assimilation of far more observations including upper air and satellite data, while the $20 \mathrm{CR}$ relies on observed synoptic surface pressures and sea surface tem15 perature boundary conditions prescribed from HadISST1 (Wake et al., 2009; Hanna et al., 2011; Compo et al., 2006, 2011; Dee et al., 2011). The 20CR temperature fluctuations are smaller in magnitude compared to ERA-I, possibly due to the lower spatial resolution of $20 \mathrm{CR}\left(2^{\circ} \times 2^{\circ}\right)$ compared to ERA-I $\left(\sim 0.75 \times 0.75^{\circ}\right)$, which could lead to artificially small $\sigma$ values from $20 \mathrm{CR}$, assuming ERA-I to be the more accurate series.

Residual differences after 1979 between the spliced and un-spliced series, when the ERA-I is incorporated into the spliced series, may be attributable to resolution differences present in the original datasets before downscaling as this latter part of the series is not affected by breakpoints. The notable convergence of temperatures after 1930 in Fig. 4 is synchronous with an increasing $\sigma$ from around 1930. This increase by $20 \mathrm{CR}$ into the model - which may well improve the calculations of both absolute temperature and its variability - with decreasing accuracy and artificially smooth temperature variability inherent before 1930 .

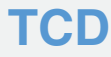

9, 5327-5371, 2015

A new spatially and temporally variable sigma parameter in degree-day melt

A. E. Jowett et al.

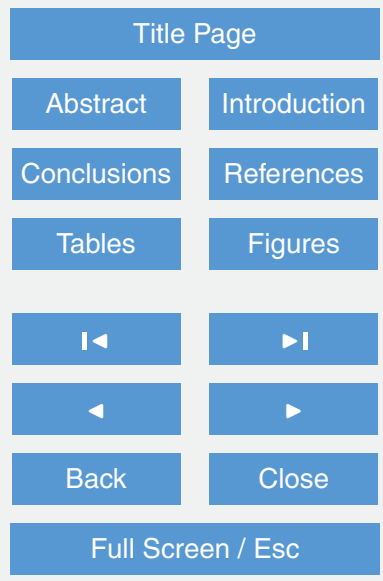

Printer-friendly Version

Interactive Discussion 
Summer is the dominant season in the melt calculation as this is when most melting takes place. Moreover, the higher $\sigma$ values above the ELA are generally of little consequence as these are in line with the constant $\sigma$ values previously used. It is therefore values below the ELA during the melt season that will have most effect on the melt cal5 culation. As the summer (especially July) $\sigma$ values are consistently lower than $4.2^{\circ} \mathrm{C}$, this has implications for the modelled melt and therefore SMB of the GrIS for the study period. As previously discussed, lower constant $\sigma$ values yield a decreased modelled melt area and a higher SMB (Fausto et al., 2009a). However, the variable parameter will likely affect the total melt volume rather than melt area as lower $\sigma$ values are evident 10 largely below the ELA during the melt season. Our results give a mean 1870-2013 summer $\sigma$ value averaged across the entire ice sheet of $\sim 3.2^{\circ} \mathrm{C}$, which is $\sim 1-2^{\circ} \mathrm{C}$ lower than in many studies. Indeed some values around the ice sheet periphery are at least five times smaller than some constant parameters discussed in Rogozhina and Rau (2014). Our summer $\sigma$ values range from $0-5^{\circ} \mathrm{C}$ over the whole ice sheet and $150-4{ }^{\circ} \mathrm{C}$ in the ablation zone. These values are overall higher than the $1-2.5^{\circ} \mathrm{C}$ that Rogozhina and Rau (2014) obtained for summer $\sigma$ based on ERA-40 reanalysis from 1958-2001. Their shorter time series, different model used and lower spatial resolution $(10 \mathrm{~km} \times 10 \mathrm{~km}$ compared to our $5 \mathrm{~km} \times 5 \mathrm{~km})$, which tends to smear the edges of the ice sheet, are likely to account for some of the differences in calculated $\sigma$.

The statistically significant increases in $\sigma$ through time over the study period in Fig. 11 would predict that the melt area has increased on average for the last 144 years. This would result in a downward trend in SMB from 1870-2013, in line with the results of Rogozhina and Rau (2014) to be investigated in a planned study into SMB of the GrlS using our variable $\sigma$. Part of this trend may, however, be due to an increasing number of weather stations assimilated into the 20CR series capturing more surface air temperature variability during the second half of the reanalysis period.

There is considerable variation in the spatial distribution of $\sigma$ on both the inter- and intra-annual timescales for the period of study. Banding with elevation is evident in all seasons, in agreement with the findings of Fausto et al. (2009b), but is less evi-

A new spatially and temporally variable sigma parameter in degree-day melt

A. E. Jowett et al.

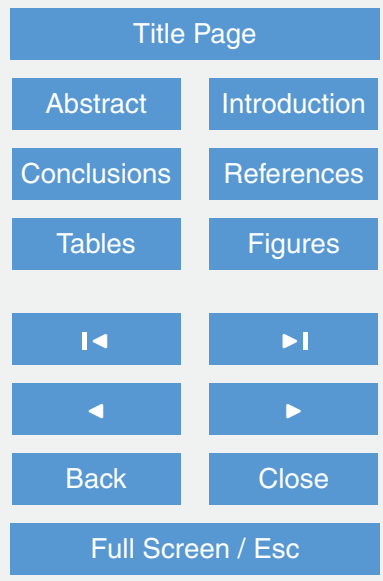

Printer-friendly Version

Interactive Discussion 
dent in the summer months. Higher $\sigma$ values in the centre of the ice sheet in Fig. 6 can be attributed to the effects of continentality and dominant more stable weather patterns with predominantly clearer skies further inland (Taurisano et al., 2004). The lower $\sigma$ values in coastal areas may be attributed to temperature inversions and greater 5 cloud cover (suppressing the diurnal temperature range) for much of the year (Cappelen et al., 2001; Mernild and Liston, 2010). The south-west of the GrIS also tends to have higher $\sigma$ values due to transient low-pressure systems moving eastwards from the Labrador Sea, especially in summer. Winter $\sigma$ values tend to be larger (Fig. 6) due to the intense cold that often dominates the centre of the ice sheet during these 10 months, which is sometimes interrupted by the intrusion of transient weather systems, especially in the south and south east, thus leading to large shifts in temperature (Box, 2002; Hanna et al., 2012). The banding with elevation is less noticeable during the summer months due to the limiting effect of melt on near-surface temperatures, as discussed previously.

15 The spatial and temporal variations in $\sigma$ across the GrIS underscore the importance of including a variable parameter in the temperature-index method. As Fausto et al. (2009a) found a $33 \%$ difference in melt area with a $\sim 2^{\circ} \mathrm{C}$ variation in a spatially and temporally constant $\sigma$, following their results the $\sim 1^{\circ} \mathrm{C}$ lower summer $\sigma$ found here could reduce the melt area by over $15 \%$. The impact of this change in melt area on the SMB, particularly during summer months: will be quantified using our updated version of the Janssens and Huybrechts (2000) PDD model. The effect of increased $\sigma$ in other months and seasons also needs to be investigated to determine whether this compensates in part for the effect of lower summer $\sigma$ or has little impact on the melt calculation. This will be presented elsewhere.

25 Validation of the new $\sigma$ parameter is difficult due to the limited spatial and temporal coverage of in situ surface air temperature observational data available for Greenland. There is inevitably more data available for areas around and surrounding the ice-sheet margin, which may introduce bias into the validation, alongside some issues concerning the independence of the validation and reanalysis meteorological datasets. As the

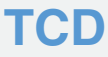

9, 5327-5371, 2015

A new spatially and temporally variable sigma parameter in degree-day melt

A. E. Jowett et al.

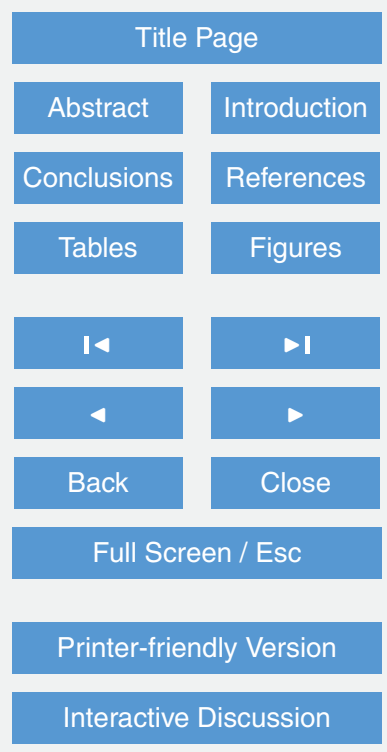


AWS temperatures are fed into the $\sigma$ parameter, either directly through least-squares fit or more indirectly through reanalysis products, this may affect the validation results by producing stronger correlations than would be the case for entirely independent datasets (Compo et al., 2011; Dee et al., 2011; Fausto et al., 2009b). On the other 5 hand, the ice-sheet margin areas are where most melt occurs, and many of the weather stations are in relatively close proximity to this region.

Data gaps are inherent in the DMI, GC-Net and PROMICE AWS data used here, which can limit the validation and introduce errors. To mitigate this issue, only stations with over two thirds complete data were included in the validation. The time period of available data also varies by station, so care was taken to ensure that the same time period was selected for the modelled $\sigma$ as was available for the corresponding station, limiting errors and making the full use of available observations. For a full description of errors in the validation data, we refer the reader to DMI TR 11-16 (DMI), van As et al. (2011) (PROMICE) and Steffen and Box (2001) (GC-Net). The point-to-pixel 15 comparison carried out in this study will inevitably also introduce some errors into the validation. Comparing a $5 \mathrm{~km} \times 5 \mathrm{~km}$ pixel with a single AWS point introduces issues of scale incompatibility; however, this technique has been used in previous studies, including those of Hanna and Valdes (2001) and Radić and Hock (2006).

Some $81 \%$ of $\sigma_{\mathrm{am}}, 62 \% \sigma_{\mathrm{jjam}}$ and $57 \% \sigma_{\mathrm{jm}}$ are within $\pm 1{ }^{\circ} \mathrm{C}$ of $\sigma$ calculated from 20 observations (Tables 2, 3 and 4). These percentages are lower than those of Fausto et al. (2009b) where $93 \%$ of summer $\sigma$ were within $1{ }^{\circ} \mathrm{C}$ of observations (Table 1), and Fausto et al. (2011) where $93 \%$ of annual and $96 \%$ of July $\sigma$ values were within $1{ }^{\circ} \mathrm{C}$ of the observations (Table 2). There is also an increase in accuracy with elevation up to the ELA $(\sim 1500 \mathrm{~m})$, with a decrease thereafter in our study. This may be due to struggles to capture the observations, and differences in the nature of the calculation between these two studies - with Fausto using AWS data to carry out least-squares fit on observed $\sigma$ rather than using (as here) downscaled, corrected reanalysis data. 
Figure 13 shows high correlation coefficients of $0.73,0.76,0.79$ and 0.82 for annual, spring, autumn and winter respectively. These correlation coefficients are all statistically significant showing a strong positive significant relationship between temperature variability calculated from 20CR and ERA-I for the overlap period 1979-2008. The 5 summer and July plots however, show weaker correlations between 20CR and ERA-I, with a positive bias in 20CR compared to ERA-I of $\sim 0.76^{\circ} \mathrm{C}$ in summer and $0.7^{\circ} \mathrm{C}$ in July for the overlap period. These correlations are still statistically significant, showing there is a significant relationship between 20CR and ERA-I $\sigma$ from 1979-2008, despite the spread about the trend line.

10 A unique aspect of the present work is the assessment of trends in $\sigma$ over the last 144 years for each $5 \mathrm{~km} \times 5 \mathrm{~km}$ pixel on the ice sheet. The significant trends in $\sigma$ across the ice sheet shown in all plots (with the two previously-highlighted exceptions) indicate that $\sigma$ has increased from 1870-2013 and therefore temperatures have become more variable across the ice sheet over the last 144 years. This increase is especially promi15 nent in the southern region for all plots, and also in the north-west for all seasons. Other studies (e.g. Hall et al., 2013) have found the greatest increase in temperatures in these regions of the GrIS, indicating that not only are these regions becoming warmer, but they have also experienced increased high-frequency (sub-monthly) temperature variability. This is unsurprising given the extent of recent warming with accompanying more frequent and extreme warm air/melt episodes over Greenland (Hanna et al., 2008, 2014; Overland et al., 2012, 2015), and stronger Greenland high-pressure blocking coupled with increasingly variable winter NAO over the last 100 years (Hanna et al., 2013, 2015). Also the assimilation of more weather stations into 20CR during the latter half of the 1870-2013 period is likely to have had an adverse effect of increasing variability in temperatures because this enhances the effective spatial resolution and sensitivity of the reanalysis. On the other hand, given the positive bias in 20CR $\sigma$ shown in Fig. 13, the 1870-2013 trend may be an underestimate if ERA-I is assumed to be the more accurate re-analysis and therefore $20 \mathrm{CR}$ is overestimating variability. The balance of these various effects will influence the observed trend.

\section{TCD}

9, 5327-5371, 2015

A new spatially and temporally variable sigma parameter in degree-day melt

A. E. Jowett et al.

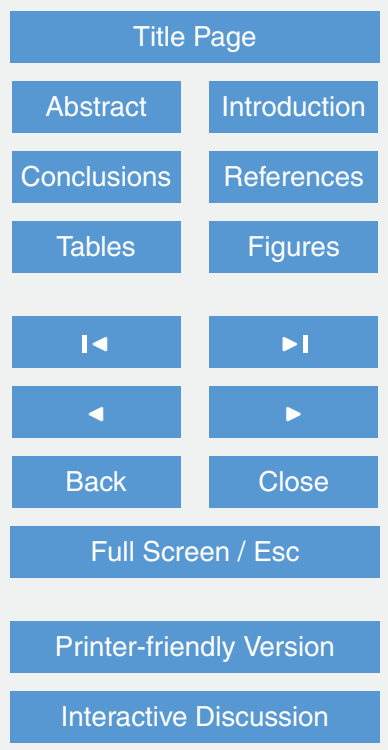


However, when the more recent period (1990-2013) is examined separately, the trends become more complex with fewer areas of statistical significance than for the 144 year trend. The presence of negative trends in all these plots for the shorter/recent timescale suggests that temperatures became less variable across large parts of the 5 ice sheet during this period. Interestingly, in the north-west in July there is a statistically significant area of reduced $\sigma$, indicating reduced temperature variability here since 1990. This could be due to more widespread, intense and longer-lasting summer melt suppressing near-surface air temperatures at around freezing for longer in summer. This was coincident with a time of more negative summer NAO, leading to 10 more southerly warm air advection and amplified Greenland warming in the last 1-2 decades (Hanna et al., 2015; Overland et al., 2012, 2014).

Figure 14 shows correlations between $\sigma$ and NAOI/GBI for summer for different time periods. The GBI-v. $-\sigma$ plot for 1990-2013 shows significant negative correlations $(<-0.4)$ along parts of the western margin, going slightly inland, and in extreme north15 west Greenland. Temperature variability is less in these regions with high GBI, due to more stable prevailing weather conditions under high pressure. There is an opposite, negative correlation along the southeast Greenland coast due to this being on the other side of the high pressure block and therefore more subject to associated vagaries in weather conditions, e.g. sometimes affected by strong cold northerly winds flowing south along the Denmark Strait due to changes in the position/intensity of the High. The pattern of GBI- $\sigma$ correlations for $1948-2013$ is similar but somewhat muted (but is broadly similar as significance levels are then lower). The NAO-v.- $\sigma$ 1899-2013 plot shows modest but significant positive correlations over most of the GrIS, which are associated with less blocking and more variable temperatures under a high NAO regime.

25 The NAO- $\sigma$ plot for 1990-2013 shows an area of significant negative correlation in inland southeast Greenland, which rather resembles the area of opposite correlation in the $\mathrm{GBI}-\sigma$ plot for the same time period.

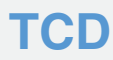

$9,5327-5371,2015$

A new spatially and temporally variable sigma parameter in degree-day melt

A. E. Jowett et al.

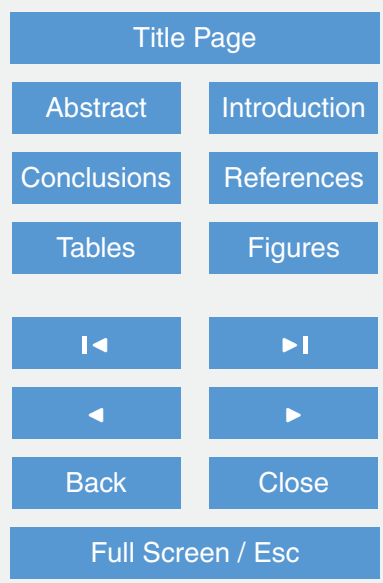

Printer-friendly Version

Interactive Discussion 


\section{Conclusions}

This work uniquely builds on previous studies by extending the timescale of currently available monthly $\sigma$ grids back to 1870 by using post-processed 20CR surface air temperature dataset as input to the standard deviation. This goes some way towards an5 swering the call for "realistic $\sigma$ values under climate conditions different from today" by Seguinot and Rogozhina (2014). To our knowledge, no other studies have determined $\sigma$ from ERA-I at the $5 \mathrm{~km}$ scale, nor have they utilised 20CR to compute $\sigma$ fields. Although the 20CR series may be considered less accurate than other products (e.g. ERA-I), the inclusion of our new three-step correction procedure helps mitigate against the inaccuracies of the series, as evidenced by the promising validation results. The use of the resulting spliced 144 year temperature/ $\sigma$ annual/seasonal $/$ monthly time series has enabled a more thorough investigation into trends of temperature variability across the GrIS on a variety of timescales than has previously been possible. Our new $\sigma$ parameter shows large deviations from the commonly assumed value of $4.2^{\circ} \mathrm{C}$, particularly during the summer months when melt intensifies. We therefore conclude that incorporating our spatially and temporally varying $\sigma$ factor provides a marked improvement over using a constant $\sigma$ value, especially for the early part of the record where $\sigma$ is shown to be much lower than many values prescribed in the literature for summer. Moreover, given the high temporal and spatial variability of $\sigma$, our results suggest that it is best to calculate $\sigma$ values each month, for example in $x$-hourly timesteps, before application of any PDD model. Also we argue that a constant $\sigma$ value cannot be used for future projections as the predicted increase in summer temperatures should result in a reduced $\sigma$ as the surface temperature is limited to $0^{\circ} \mathrm{C}$.

This work offers a more comprehensive validation of ERA-I/20CR based $\sigma$ against
AWS data than previous studies, as here we have incorporated 67 sites from across the ice sheet. The overall agreement between modelled and observed $\sigma$ indicates that our new parameter realistically approximates sub-monthly temperature variability at the $5 \mathrm{~km}$ scale across the GrIS. Our trends show a clear increase in $\sigma$ across the ice sheet
A new spatially and temporally variable sigma parameter in degree-day melt

A. E. Jowett et al.

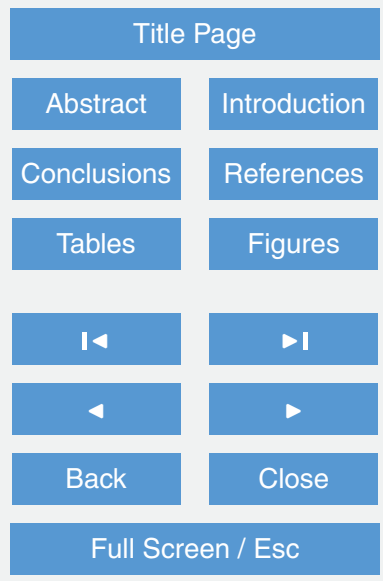

Printer-friendly Version

Interactive Discussion 
from 1870-2013, which adds to the recent weight of evidence for increasing climatic variability over the ice sheet. Over the recent short period 1990-2013, the temporal trends expressed by $\sigma$ illustrate how regionally variable this parameter is, despite the lack of statistical significance in most areas. Based on the preceding analysis, we con5 clude that our results provide a more realistic long-term (1870-2013) parameter of $\sigma$ for input into PDD models of the GrIS SMB.

Acknowledgements. We would like to thank the Natural Environment Research Council for funding this $\mathrm{PhD}$ (NERC reference number NE/K500 914/1). Further acknowledgement must be extended to the Danish Meteorological Institute, the Greenland Climate Network, Programme

onitoring of the Greenland Ice Sheet, the National Centre for Atmospheric Research, Computational and Information Systems Laboratory for providing 20CR version 2 data and the European Centre for Medium-Range Weather Forecasts for providing data without which this work would not have been possible. Within the department of Geography at the University of Sheffield we would like to thank David McCutcheon for his cartography skills in re-drafting our 15 figures.

\section{References}

Ahlstrøm, A. P. and PROMICE team: A new programme for monitoring the mass loss of the Greenland ice sheet, Geol. Surv. Den. Greenl., 15, 61-64, 2008.

Box, J. E.: Survey of Greenland instrumental temperature records: 1873-2001, Int. J. Climatol., 20 22, 1829-1847, 2002.

Braithwaite, R. J.: Calculation of degree-days for glacier-climate research, Z. Gletscherk. Glazialgeol., 20, 1-8, 1984.

Braithwaite, R. J.: Positive degree-day factors for ablation on the Greenland ice sheet studied by energy-balance modelling, J. Glaciol., 41, 153-160, 1995.

25 Cappelen, J., Jørgensen, B. V., Laursen, E. V., and Thomsen, L.: The observed climate of Greenland, 1958-99 - with climatological standard normal, 1961-90, DMI Technical Report 00-18, DMI, Copenhagen, 2001.
A new spatially and temporally variable sigma parameter in degree-day melt

A. E. Jowett et al.

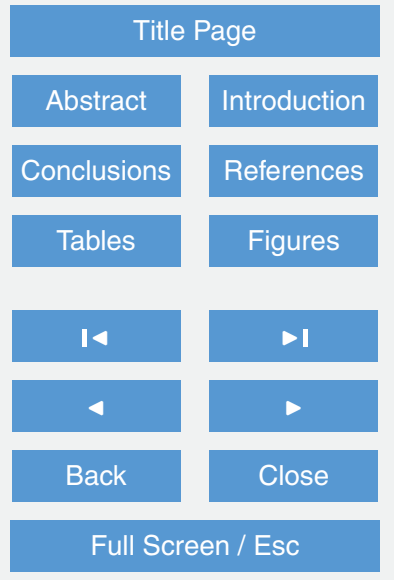

Printer-friendly Version

Interactive Discussion 
Cappelen, J., Laursen, E. V., Kern-Hansen, K., Boas, L., Wang, P. R., Jørgensen, B. V., and Carstensen, L. S.: Weather observations from Greenland 1958-2012, DMI Technical Report 13-11, DMI, Copenhagen, 2013.

Compo, G. P., Whitaker, J. S., and Sardeshmukh, P. D.: Feasibility of a 100 year reanalysis using only surface pressure data, B. Am. Meteorol. Soc., 87, 175-190, 2006.

Compo, G. P., Whitaker, J. S., Sardeshmukh, P. D., Matsui, N., Allan, R. J., Yin, X., Gleason, B. E., Vose, R. S., Rutledge, G., Bessemoulin, P., Brönnimann, S., Brunet, M., Crouthamel, R. I., Grant, A. N., Groisman, P. Y., Jones, P. D., Kruk, M. C., Kruger, A. C., Marshall, G. J., Maugeri, M., Mok, H. Y., Nordli, Ø., Ross, T. F., Trigo, R. M., Wang, X. L., Woodruff, S. D., and Worley, S. J.: The Twentieth Century Reanalysis Project, Q. J. Roy. Meteorol. Soc., 137, 1-28, doi:10.1002/qj.776, 2011.

Danish Meteorological Institute: Quality control of Greenlandic weather and climate data series 1958-2010: Supplement to Technical Report 11-15, DMI Ministry of Climate and Energy, Copenhagen, 2011.

Dee, D. P., Uppala, S. M., Simmons, A. J., Berrisford, P., Poli, P., Kobayashi, S., Andrae, U., Balmaseda, M. A., Balsamo, G., Bauer, P., Bechtold, P., Beljaars, A. C. M., van de Berg, L., Bidlot, J., Bormann, N., Delsol, C., Dragani, R., Fuentes, M., Geer, A. J., Haimberger, L., Healy, S. B., Hersbach, H., Hólm, E. V., Isaksen, L., Kållberg, P., Köhler, M., Matricardi, M., McNally, A. P., Monge-Sanz, B. M., Morcrette, J.-J., Park, B.-K., Peubey, C., de Rosnay, P., Tavolato, C., Thépaut, J.-N. and Vitart, F.: The ERA-Interim reanalysis: configuration and performance of the data assimilation system, Q. J. Roy. Meteorol. Soc., 137, 553-597, doi:10.1002/qj.828, 2011.

Ekholm, S.: A full coverage, high-resolution, topographic model of Greenland computed from a variety of digital elevation data, J. Geophys. Res., 101, 21961-21972, 1996.

Fausto, R. S., Ahlstrøm, A. P., Van As, D., Bøggild, C. E., and Johnsen, S. J.: A new present-day temperature parameterization for Greenland, J. Glaciol., 55, 95-105, 2009a.

Fausto, R. S., Ahlstrøm, A. P., Van As, D., Johnsen, S. J., Langen, P. L., and Steffen, K.: Improving surface boundary conditions with focus on coupling snow densification and meltwater retention in large-scale ice-sheet models of Greenland, J. Glaciol., 55, 869-878, 2009b.

30 Fausto, R. S., Ahlstrøm, A. P., Van As, D., and Steffen, K.: Present-day temperature standard deviation parameterization for Greenland, J. Climate, 57, 1181-1183, 2011.
TCD

9, 5327-5371, 2015

A new spatially and temporally variable sigma parameter in degree-day melt

A. E. Jowett et al.

Title Page

\section{Abstract} Introduction

Conclusions References

Tables Figures

14

4

Back

Full Screen / Esc

Printer-friendly Version

Interactive Discussion 
Ferguson, C. R. and Villarini, G.: Detecting inhomogeneities in the Twentieth Century Reanalysis over the central United States, J. Geophys. Res., 117, D05123, doi:10.1029/2011JD016988, 2012.

Ferguson, C. R. and Villarini, G.: An evaluation of the statistical homogeneity of the Twentieth Century Reanalysis, Clim. Dynam., 42, 2841-2866, 2014.

Hall, D. K., Comiso, J. C., DiGirolamo, N. E., Shuman, C. A., Box, J. E., and Koenig, L. S.: Variability in surface temperature and melt extent of the Greenland ice sheet from MODIS, Geophys. Res. Lett., 40, 2114-2120, 2013.

Hanna, E. and Valdes, P.: Validation of ECMWF (re)analysis surface climate data, 1979-1998, for Greenland and implications for mass balance modelling of the ice sheet, Int. J. Climatol., 21, 171-195, 2001.

Hanna, E., Huybrechts, P., Janssens, I., Cappelen, J., Steffen, K., and Stephens, A.: Runoff and mass balance of the Greenland ice sheet: 1958-2003, J. Geophys. Res., 110, D13108, doi:10.1029/2004JD005641, 2005.

Hanna, E., Huybrechts, P., Steffen, K., Cappelen, J., Huff, R., Shuman, C., Irvine-Fynn, T., Wise, S., and Griffiths, M.: Increased runoff from melt from the Greenland Ice Sheet: a response to global warming, J. Climate, 21, 331-341, 2008.

Hanna, E., Huybrechts, P., Cappelen, J., Steffen, K., Bales, R. C., Burgess, E., McConnell, J. R., Steffensen, J. P., Van den Brooke, M., Wake, L., Bigg, G., Griffiths, M., and Savas, D.: Greenland Ice Sheet surface mass balance 1870 to 2010 based on Twentieth Century Reanalysis, and links with global climate forcing, J. Geophys. Res., 116, D24121, doi:10.1029/2011JD016387, 2011.

Hanna, E., Mernild, S. H., Cappelen, J., and Steffen, K.: Recent warming in Greenland in a long-term instrumental (1881-2012) climatic context: 1. Evaluation of surface air temperature records, Environ. Res. Lett., 7, 045404, doi:10.1088/1748-9326/7/4/045404, 2012.

Hanna, E., Jones, J. M., Cappelen, J., Mernild, S. H., Wood, L., Steffen, K., and Huybrechts, P.: The influence of North Atlantic atmospheric and oceanic forcing effects on 1900-2010 Greenland summer climate and ice melt/runoff, Int. J. Climatol., 33, 862-880, 2013.

Hanna, E., Fettweis, X., Mernild, S. H., Cappelen, J., Ribergaard, M. H., Shuman, C. A., Steffen, K., Wood, L., and Mote, T. L.: Atmospheric and oceanic climate forcing of the exceptional Greenland ice sheet surface melt in summer 2012, Int. J. Climatol., 34, 1022-1037, 2014.

Hanna, E., Cropper, T. E., Jones, P. D., Scaife, A. A., and Allan, R.: Recent seasonal asymmetric changes in the NAO (a marked summer decline and increased winter variability) and asso-

A new spatially and temporally variable sigma parameter in degree-day melt

A. E. Jowett et al.

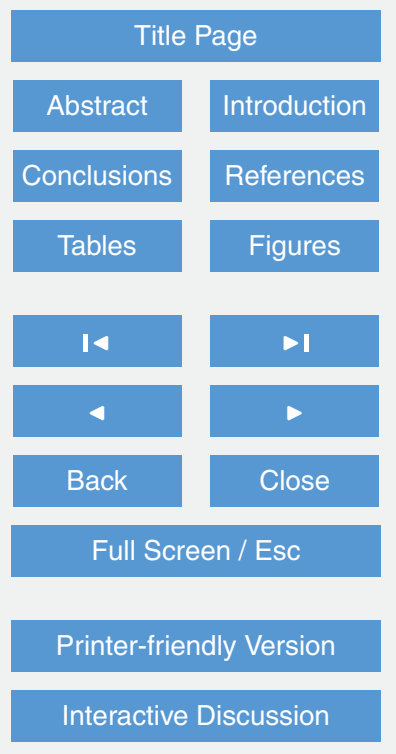

Interactive Discussion

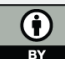


ciated changes in the AO and Greenland Blocking Index, Int. J. Climatol., 35, 2540-2554, doi:10.1002/joc.4157, 2015.

Hock, R.: Temperature index melt modelling in mountain areas, J. Hydrol., 282, 104-115, 2003.

Huybrechts, P. and de Wolde, J.: The dynamic response of the Greenland and Antarctic ice sheets to multiple-century climatic warming, J. Climate, 12, 2169-2188, 1999.

Janssens, I. and Huybrechts, P.: The treatment of meltwater retention in mass balance parameterizations of the Greenland ice sheet, Ann. Glaciol., 31, 133-140, 2000.

Lefebre, F., Gallée, H., Van Ypersele, J.-P., and Huybrechts, P.: Modelling of large-scale melt parameters with a regional climate model in south Greenland during the 1991 melt season,

10 Ann. Glaciol., 32, 391-397, 2002.

Mernild, S. H. and Liston, G. E.: The influence of air temperature inversions on snowmelt and glacier mass balance simulations, Ammassalik Island, Southeast Greenland, J. Appl. Meteorol. Clim., 49, 47-67, 2010.

Overland, J. E., Francis, J. A., Hanna, E., and Wang, M.: The recent shift in early summer Arctic atmospheric circulation, Geophys. Res. Lett., 39, L19804, doi:10.1029/2012GL053268, 2012.

Overland, J. E., Hanna, E., Hanssen-Bauer, I., Kim, S.-J., Walsh, J., Wang, M., and Bhatt, U. S.: Air temperature [in Arctic Report Card 2014], available at: www.arctic.noaa.gov/reportcard (last access: 27 August 2015), 2014.

20 Overland, J. E., Francis, J., Hall, R. J., Hanna, E., Kim, S.-J., and Vihma, T.: The melting Arctic and mid-latitude weather patterns: are they connected?, J. Climate, doi:10.1175/JCLI-D-1400822.1, in press, 2015.

Radić, V. and Hock, R.: Modeling future glacier mass balance and volume changes using ERA40 reanalysis and climate models: a sensitivity study at Storglaciären, Sweden, J. Geophys. Res., 111, F03003, doi:10.1029/2005JF000440, 2006.

Reeh, N.: Parameterization of melt rate and surface temperature on the Greenland ice sheet, Polarforschung, 59, 113-128, 1991.

Ritz, C., Kanagaratnam, P., and Letréguilly, A.: Sensitivity of a Greenland ice sheet model to ice flow and ablation parameters: consequences for the evolution through the last glacial cycle, 30 Clim. Dynam., 13, 11-24, 1997.

Rogozhina, I. and Rau, D.: Vital role of daily temperature variability in surface mass balance parameterizations of the Greenland Ice Sheet, The Cryosphere, 8, 575-585, doi:10.5194/tc8-575-2014, 2014.

A new spatially and temporally variable sigma parameter in degree-day melt

A. E. Jowett et al.

Title Page

Abstract Introduction

Conclusions References

Tables Figures

14

4

Back

Close

Full Screen / Esc

Printer-friendly Version

Interactive Discussion
>I 
Seguinot, J.: Spatial and seasonal effects of temperature variability in a positive degree-day glacier surface mass-balance model, J. Glaciol., 59, 1202-1204, 2013.

Seguinot, J. and Rogozhina, I.: Daily temperature variability predetermined by thermal conditions over ice-sheet surfaces, J. Glaciol., 60, 603-605, 2014.

5 Steffen, K. and Box, J. E.: Surface climatology of the Greenland ice sheet: Greenland Climate Network 1995-1999, J. Geophys. Res., 106, 33951-33964, 2001.

Steffen, K., Box, J. E., and Abdalati, W.: Greenland Climate Network: CG-Net in Colbeck, S. C., CRREL 96-27 Special Report on Glaciers, Ice Sheets and Volcanoes, trib. to M. Meier, US Army Corp of Engineers Cold Regions Research and Engineering Laboratory, Hanover,

$10 \mathrm{NH}, 98-103,1996$.

Taurisano, A., Bøggild, C. E., and Karlsen, H. G.: A century of climate variability and climate gradiaents from coast to ice sheet in West Greenland, Geograf. Ann. A, 86, 217-224, 2004.

Uppala, S. M., Kållberg, P. W., Simmons, A. J., Andrae, U., Bechtold, V. D. C., Fiorino, M., Gibson, J. K., Haseler, J., Hernandez, A., Kelly, G. A., Li, X., Onogi, K., Saarinen, S., Sokka, N., Allan, R. P., Andersson, E., Arpe, K., Balmaseda, M. A., Beljaars, A. C. M., Berg, L. V. D., Bidlot, J., Bormann, N., Caires, S., Chevallier, F., Dethof, A., Dragosavac, M., Fisher, M., Fuentes, M., Hagemann, S., Hólm, E., Hoskins, B. J., Isaksen, L., Janssen, P. A. E. M., Jenne, R., Mcnally, A. P., Mahfouf, J.-F., Morcrette, J.-J., Rayner, N. A., Saunders, R. W., Simon, P., Sterl, A., Trenberth, K. E., Untch, A., Vasiljevic, D., Viterbo, P., and Woollen, J.: The ERA-40 re-analysis, Q. J. Roy. Meteorol. Soc., 131, 2961-3012, doi:10.1256/qj.04.176, 2005.

van As, D., Fausto, R. S., and the PROMICE project team: Programme for monitoring of the Greenland Ice Sheet (PROMICE): first temperature and ablation records, Geol. Surv. Den. Greenl., 23, 73-76, 2011.

Van de Wal, R. S. W., Boot, W., van den Brooke, M. R., Smeets, C. J. P. P., Reijmer, C. H., Donker, J. J. A., and Oerlemans, J.: Large and rapid melt-induced velocity changes in the ablation zone of the Greenland Ice Sheet, Science, 321, 111-113, 2008.

Wake, L. M. and Marshall, S. J.: Assessment of current methods of positive degree-day calculation using in situ observations from glaciated regions, J. Glaciol., 61, 329-344, 2015.

30 Wake, L. M., Huybrechts, P., Box, J. E., Hanna, E., Janssens, I., and Milne, G. A.: Surface mass-balance changes of the Greenland ice sheet since 1866, Ann. Glaciol., 50, 178-184, 2009. 
Table 1. The five months where breakpoints were detected are displayed at the top of the table. The year at which the breakpoint for that month was detected is displayed below, followed by the confidence intervals in $2 \mathrm{~m}$ air temperature from 1870-2013. These were identified using Bai-Perron breakpoint analysis in $R$. The results displayed here are those for the months where breakpoints were identified in both the $2 \mathrm{~m}$ air temperature and the spread of $2 \mathrm{~m}$ air temperature, deemed to be due to the model, not climatology. The mean $2 \mathrm{~m}$ air temperature before and after the breakpoint for each month is also displayed along with the difference between them. This difference (displayed to 2 d.p. here) was taken as the correction factor and applied to 3 hourly and monthly $2 \mathrm{~m}$ air temperature before the breakpoint for that month.

\begin{tabular}{llllll}
\hline Month of breakpoint & Mar & Apr & Aug & Sep & Oct \\
\hline Year of breakpoint & 1946 & 1941 & 1912 & 1941 & 1966 \\
Confidence Intervals & $1930-1959$ & $1921-1948$ & $1872-1927$ & $1899-1966$ & $1941-1985$ \\
Mean before breakpoint $\left({ }^{\circ} \mathrm{C}\right)$ & -27.79 & -21.85 & -7.89 & -14.69 & -21.68 \\
Mean after breakpoint $\left({ }^{\circ} \mathrm{C}\right)$ & -29.87 & -23.45 & -8.61 & -15.64 & -23.12 \\
Difference $\left({ }^{\circ} \mathrm{C}\right)$ & 2.08 & 1.6 & 0.72 & 0.95 & 1.44 \\
\hline
\end{tabular}

A new spatially and temporally variable sigma parameter in degree-day melt

A. E. Jowett et al.

Title Page

Abstract

14

$<$

Back

\section{Full Screen / Esc}

Printer-friendly Version 
Table 2. Annual, summer and July modelled $\sigma$ and that derived from DMI AWS observations, and the differences between them. The stations with the longest running and most complete observational record for $2 \mathrm{~m}$ air temperatures were chosen for the analysis to validate $\sigma$ for the period pre-1979 (from 20CR) as well as the more readily available post-1979 period (from ERA-I).

\begin{tabular}{lcccrccccccc}
\hline Station & $\begin{array}{c}\text { Years } \\
\text { data }\end{array}$ & $\sigma_{a}$ & $\sigma_{a}^{m}$ & Diff. & $\sigma_{\text {jja }}$ & $\sigma_{\text {jja }}^{m}$ & Diff. & $\sigma_{j}$ & $\sigma_{j}^{m}$ & Diff. \\
\hline 4202 & 29 & 4.70 & 4.02 & -0.69 & 2.76 & 1.81 & -0.96 & 2.83 & 1.62 & -1.21 \\
4207 & 13 & 5.03 & 4.67 & -0.36 & 3.18 & 2.66 & -0.52 & 2.94 & 2.28 & -0.66 \\
4210 & 29 & 4.31 & 3.86 & -0.45 & 2.98 & 1.96 & -1.02 & 3.07 & 1.75 & -1.31 \\
4211 & 11 & 4.00 & 3.63 & -0.37 & 3.24 & 2.10 & -1.15 & 3.35 & 2.06 & -1.29 \\
4216 & 31 & 4.86 & 4.00 & -0.86 & 2.95 & 2.30 & -0.65 & 2.90 & 2.02 & -0.88 \\
4220 & 55 & 4.14 & 3.42 & -0.72 & 2.32 & 2.11 & -0.21 & 2.40 & 2.07 & -0.34 \\
4221 & 20 & 4.70 & 5.09 & 0.39 & 2.99 & 3.11 & 0.12 & 2.84 & 3.03 & 0.19 \\
4230 & 40 & 4.16 & 3.51 & -0.64 & 2.70 & 2.27 & -0.43 & 2.82 & 2.20 & -0.62 \\
4231 & 39 & 6.39 & 5.35 & -1.04 & 3.93 & 3.26 & -0.67 & 3.91 & 3.07 & -0.84 \\
4234 & 12 & 4.02 & 3.54 & -0.48 & 3.25 & 2.32 & -0.93 & 3.46 & 2.35 & -1.11 \\
4250 & 54 & 3.70 & 3.43 & -0.27 & 2.72 & 1.94 & -0.78 & 2.82 & 1.84 & -0.98 \\
4253 & 30 & 3.03 & 3.41 & 0.38 & 1.91 & 1.94 & 0.03 & 1.94 & 1.91 & -0.04 \\
4270 & 52 & 4.91 & 4.27 & -0.64 & 3.30 & 2.40 & -0.90 & 3.24 & 2.22 & -1.02 \\
4272 & 52 & 3.99 & 3.36 & -0.63 & 3.14 & 1.89 & -1.26 & 3.20 & 1.80 & -1.40 \\
4301 & 25 & 4.67 & 2.22 & -2.45 & 2.36 & 1.21 & -1.16 & 1.94 & 0.81 & -1.12 \\
4312 & 23 & 4.98 & 3.79 & -1.19 & 3.45 & 1.68 & -1.77 & 3.53 & 1.28 & -2.24 \\
4313 & 24 & 3.97 & 3.66 & -0.30 & 1.90 & 1.39 & -0.52 & 1.74 & 1.15 & -0.59 \\
4320 & 54 & 4.59 & 3.79 & -0.80 & 2.87 & 1.62 & -1.25 & 3.05 & 1.37 & -1.67 \\
4330 & 48 & 4.55 & 3.60 & -0.95 & 2.86 & 1.67 & -1.19 & 2.89 & 1.53 & -1.36 \\
4351 & 19 & 3.52 & 3.41 & -0.11 & 2.43 & 1.90 & -0.53 & 2.64 & 1.74 & -0.89 \\
4360 & 55 & 3.84 & 3.49 & -0.35 & 2.89 & 2.12 & -0.78 & 3.04 & 1.91 & -1.13 \\
4373 & 23 & 3.09 & 3.44 & 0.34 & 2.82 & 2.15 & -0.67 & 2.85 & 2.07 & -0.78 \\
4382 & 20 & 2.43 & 2.25 & -0.18 & 2.35 & 1.47 & -0.88 & 2.50 & 1.50 & -1.00 \\
4416 & 11 & 7.39 & 5.98 & -1.41 & 5.31 & 3.93 & -1.38 & 4.63 & 3.45 & -1.17 \\
\hline & & & & & & & & & & & \\
\hline
\end{tabular}

A new spatially and temporally variable sigma parameter in degree-day melt

A. E. Jowett et al.

Title Page

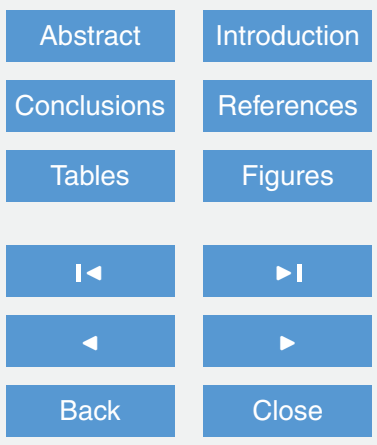

Full Screen / Esc

Printer-friendly Version

Interactive Discussion 
Table 3. Annual, summer and July modelled $\sigma$ and that derived from GC-Net AWS observations for the period since the mid-1990s.

\begin{tabular}{|c|c|c|c|c|c|c|c|c|c|c|c|}
\hline $\begin{array}{l}\text { Station } \\
\text { name }\end{array}$ & $\begin{array}{r}\text { Altitude } \\
(\mathrm{m})\end{array}$ & Period & $\sigma_{a}$ & $\sigma_{a}^{m}$ & Diff. & $\sigma_{\mathrm{jja}}$ & $\sigma_{\mathrm{jja}}^{m}$ & Diff. & $\sigma_{j}$ & $\sigma_{j}^{m}$ & Diff. \\
\hline Peterman Gl. & 37 & 2002-2006 & 5.28 & 4.98 & -0.31 & & 2.29 & -1.32 & 3.38 & 1.72 & -1.66 \\
\hline JAR3 & 283 & 2000-2004 & 4.66 & 5.39 & 0.73 & 1.95 & 3.27 & 1.32 & 1.56 & 3.09 & 1.53 \\
\hline JAR 2 & 507 & 1999-2012 & 4.70 & 5.28 & 0.59 & & 3.18 & 1.50 & & 3.05 & 1.68 \\
\hline JAR 1 & 932 & 1997-2012 & 4.92 & 5.33 & 0.41 & 2.15 & 3.02 & 0.87 & 1.91 & 2.90 & 0.98 \\
\hline Peterman ELA & 965 & 2003-2012 & - & - & - & 2.88 & 2.60 & -0.28 & 1.26 & 1.53 & 0.26 \\
\hline & 1176 & 1996-2012 & 5.50 & 5.38 & -0.11 & 2.65 & 3.01 & 0.36 & & 2.85 & 0.71 \\
\hline GITS & 1869 & 1995-2007 & 5.78 & 4.90 & -0.88 & 3.50 & 2.93 & -0.57 & & 2.41 & -0.74 \\
\hline Crawford P2 & 1990 & 1997-2001 & 6.82 & 5.53 & -1.29 & 4.18 & 3.18 & -1.00 & 3.80 & 2.94 & -0.86 \\
\hline Humboldt & 1995 & -2012 & 6.32 & 5.22 & -1.10 & 4.11 & 3.11 & -1.00 & & 2.52 & -0.84 \\
\hline ord Pt.1 & 2022 & & & 5.58 & -1.17 & & 3.13 & & & 2.89 & -0.99 \\
\hline Tunu-N & 2052 & -2012 & 5.86 & 5.03 & -0.82 & 4.28 & 3.27 & -1.00 & 3.39 & 2.52 & -0.87 \\
\hline DYE-2 & 2099 & -2012 & 6.82 & 5.64 & -1.18 & 4.27 & 3.42 & -0.85 & 3.79 & 3.18 & -0.61 \\
\hline & 2334 & -2012 & 6.95 & 5.64 & -1.31 & 4.34 & 3.26 & -1.07 & 4.07 & 2.93 & -1.14 \\
\hline NAS & 2373 & 1998-2012 & 6.89 & 5.33 & -1.56 & 4.67 & 3.45 & -1.22 & & 3.28 & -1.05 \\
\hline NEEM & 2454 & 2006-2012 & 6.45 & 5.56 & -0.89 & 4.39 & 3.08 & -1.31 & 3.78 & 2.62 & -1.16 \\
\hline Saddle & 2467 & 1997-2012 & 6.58 & 5.63 & -0.95 & 4.42 & 3.56 & -0.86 & 3.96 & 3.39 & -0.57 \\
\hline KAR & 2579 & 1999-2001 & 6.32 & 4.85 & -1.47 & 5.02 & 3.71 & -1.31 & 4.61 & 3.39 & -1.22 \\
\hline NASA-E & 2614 & 1997-2011 & 6.05 & 5.12 & -0.93 & 4.53 & 3.51 & -1.01 & 3.63 & 2.71 & -0.92 \\
\hline South Dome & 2901 & 2003-2012 & 6.04 & 5.36 & -0.68 & 4.09 & 3.69 & -0.40 & 4.04 & 3.81 & -0.23 \\
\hline & 2941 & 2002-2010 & 6.93 & 5.92 & -1.01 & 4.65 & 3.48 & -1.17 & 4.07 & 3.26 & -0.81 \\
\hline Summit & 3199 & 1996-2012 & 6.80 & 5.99 & -0.81 & 5.13 & 3.94 & -1.19 & 4.40 & 3.36 & -1.04 \\
\hline
\end{tabular}

\section{6}

A new spatially and temporally variable sigma parameter in degree-day melt

A. E. Jowett et al.

Title Page

\begin{tabular}{|c|c|}
\hline Abstract & Introduction \\
\hline Conclusions & References \\
\hline Tables & Figures \\
\hline & \\
\hline I & $>$ \\
\hline 4 & $\triangleright$ \\
\hline Back & Close \\
\hline Full Screen / Esc \\
\hline
\end{tabular}

Printer-friendly Version

Interactive Discussion 
Table 4. Annual, summer and July modelled $\sigma$ and that derived from PROMICE AWS observations since 2007, with data spanning the ablation and accumulation zones of the ice sheet.

\begin{tabular}{lrcccccccccc}
\hline Station & $\begin{array}{r}\text { Altitude } \\
(\mathrm{m})\end{array}$ & Period & $\sigma_{a}$ & $\sigma_{a}^{m}$ & Diff. & $\sigma_{\text {ija }}$ & $\sigma_{\text {jja }}^{m}$ & Diff. & $\sigma_{j}$ & $\sigma_{j}^{m}$ & Diff. \\
& 230 & $2009-2012$ & 4.24 & 4.77 & 0.54 & 1.88 & 2.60 & 0.72 & 1.47 & 2.14 & 0.67 \\
\hline UPE_L & 270 & $2007-2012$ & 2.86 & 3.86 & 1.00 & 1.68 & 2.33 & 0.65 & 1.37 & 2.10 & 0.73 \\
TAS_L & 310 & $2007-2012$ & 3.80 & 3.83 & 0.03 & 1.57 & 2.23 & 0.66 & 1.54 & 2.10 & 0.56 \\
QAS_L & 350 & $2011-2012$ & 5.48 & 6.27 & 0.80 & 2.41 & 3.37 & 0.96 & 1.99 & 3.10 & 1.11 \\
KAN_B & 380 & $2008-2012$ & 3.86 & 3.82 & -0.04 & 2.52 & 2.46 & -0.07 & 2.01 & 2.14 & 0.13 \\
KPC_L & 460 & $2009-2012$ & 3.53 & 3.67 & 0.14 & 1.94 & 2.33 & 0.39 & 1.84 & 2.01 & 0.17 \\
MIT & 470 & $2008-2012$ & 3.93 & 4.53 & 0.60 & 1.71 & 3.34 & 1.63 & 1.47 & 2.74 & 1.27 \\
SCO_L & 560 & $2008-2012$ & 5.04 & 5.98 & 0.94 & 1.93 & 3.10 & 1.18 & 1.81 & 3.08 & 1.27 \\
NUK_L & 570 & $2010-2012$ & 3.98 & 4.05 & 0.07 & 2.21 & 1.81 & -0.40 & 1.64 & 1.45 & -0.19 \\
THU_L & 580 & $2008-2012$ & 3.46 & 3.96 & 0.50 & 1.50 & 2.33 & 0.83 & 1.25 & 2.13 & 0.88 \\
TAS_U & 680 & $2009-2012$ & 4.98 & 5.65 & 0.67 & 1.61 & 3.22 & 1.61 & 1.53 & 3.27 & 1.73 \\
KAN_L & 770 & $2010-2012$ & 4.37 & 4.11 & -0.26 & 2.29 & 1.83 & -0.46 & 1.72 & 1.47 & -0.26 \\
THU_U & 870 & $2009-2012$ & 4.74 & 4.21 & -0.53 & 2.70 & 2.63 & -0.07 & 1.72 & 2.05 & 0.33 \\
KPC_U & 890 & $2008-2012$ & 3.60 & 4.26 & 0.66 & 1.92 & 2.37 & 0.45 & 1.42 & 2.29 & 0.87 \\
QAS_U & 930 & $2010-2012$ & & & & 1.65 & 2.92 & 1.27 & 1.12 & 2.64 & 1.52 \\
NUK_N & 980 & $2009-2012$ & 4.86 & 5.49 & 0.62 & 1.83 & 3.03 & 1.20 & 1.28 & 2.45 & 1.17 \\
UPE_U & 1000 & $2008-2012$ & 4.21 & 4.50 & 0.29 & 2.16 & 3.43 & 1.27 & 1.51 & 2.79 & 1.27 \\
SCO_U & 1140 & $2007-2012$ & 5.07 & 5.86 & 0.79 & 1.88 & 3.10 & 1.22 & 1.49 & 2.73 & 1.24 \\
NUK_U & 1270 & $2009-2012$ & 5.67 & 5.61 & -0.06 & 2.14 & 3.03 & 0.88 & 1.77 & 3.07 & 1.29 \\
KAN_M & 1850 & $2009-2012$ & & & & 3.56 & 3.44 & -0.11 & 3.09 & 3.51 & 0.42 \\
KAN_U & 230 & $2009-2012$ & 4.24 & 4.77 & 0.54 & 1.88 & 2.60 & 0.72 & 1.47 & 2.14 & 0.67 \\
UPE_L & 270 & $2007-2012$ & 2.86 & 3.86 & 1.00 & 1.68 & 2.33 & 0.65 & 1.37 & 2.10 & 0.73 \\
TAS_L & & & & & & & & & & & \\
\hline
\end{tabular}

\section{9, 5327-5371, 2015}

A new spatially and temporally variable sigma parameter in degree-day melt

A. E. Jowett et al.

Title Page

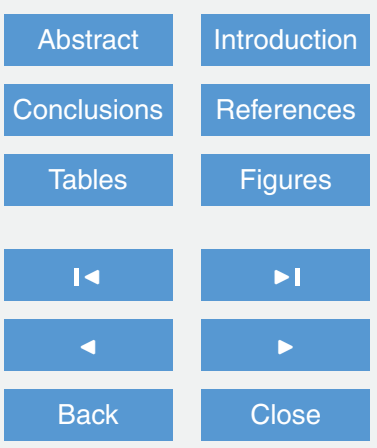

Full Screen / Esc

Printer-friendly Version

Interactive Discussion 


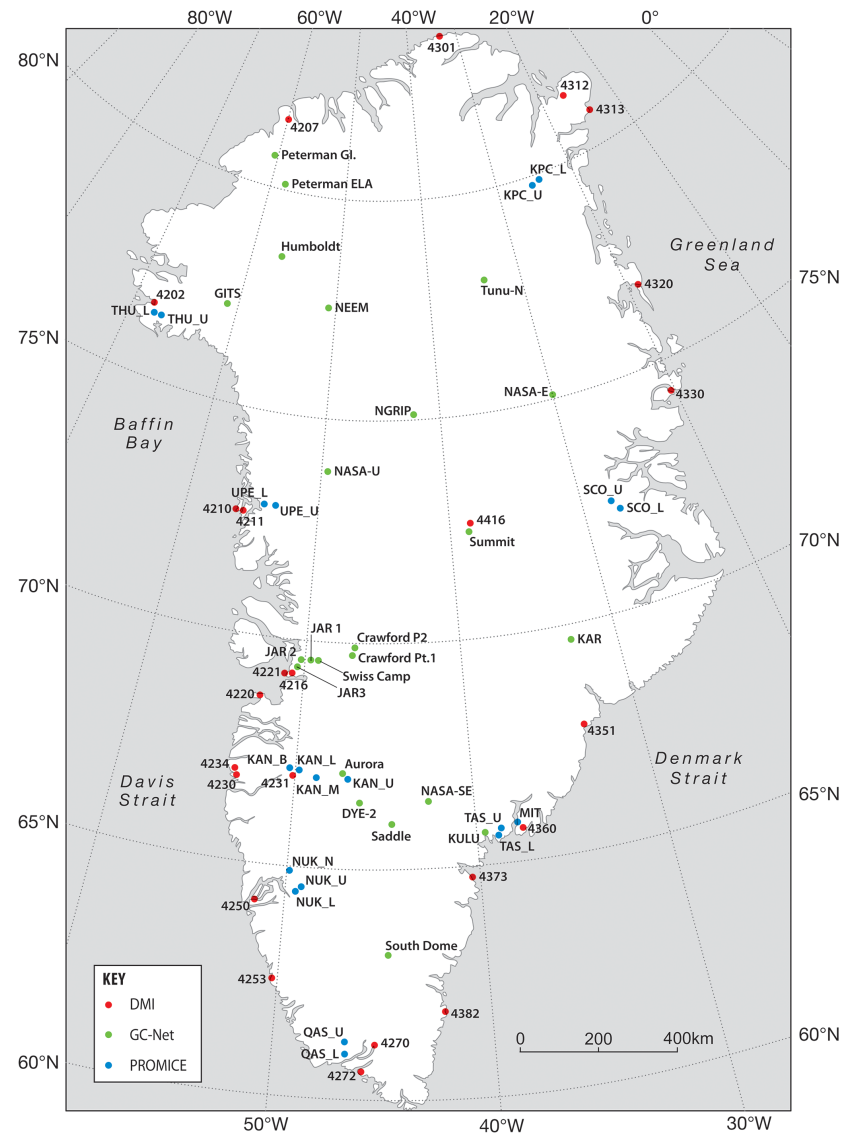

Figure 1. Location map of the DMI, GC-Net and PROMICE AWS providing the observed $2 \mathrm{~m}$ air temperature data used in the validation of our new variable $\sigma$ parameter.
TCD

9, 5327-5371, 2015

A new spatially and temporally variable sigma parameter in degree-day melt

A. E. Jowett et al.

\section{Title Page}

Abstract

Introduction

Conclusions

References

Tables

Figures

14

Back

Close

Printer-friendly Version

Interactive Discussion 

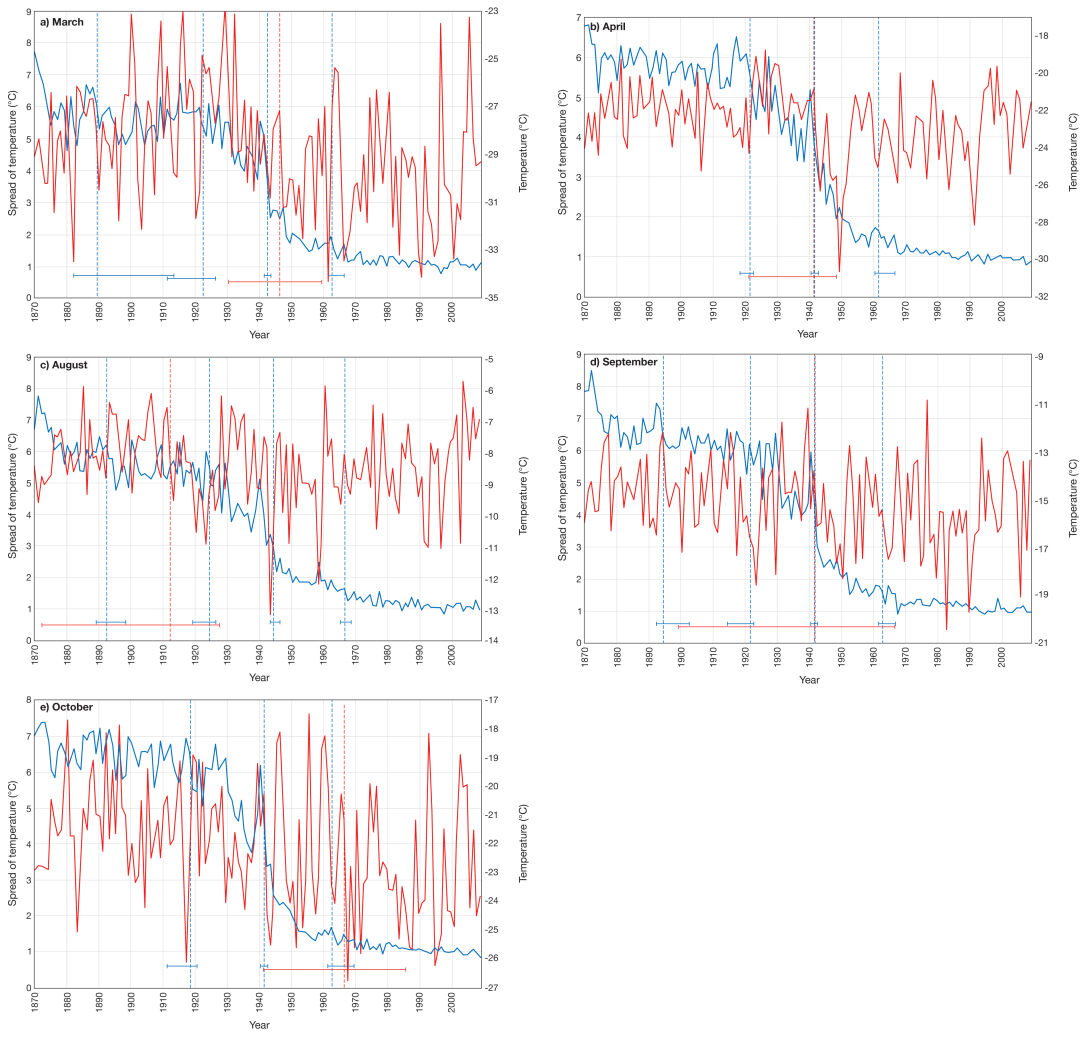

Figure 2. (a) March, (b), April, (c) August, (d) September, and (e) October breakpoints (vertical lines) in ice sheet averaged $2 \mathrm{~m}$ air temperature (red) and the spread of $2 \mathrm{~m}$ air temperatures (blue) from 1870-2013, with confidence intervals (horizontal lines) determined from Bai-Perron breakpoint analysis in $\mathrm{R}$. The mean $2 \mathrm{~m}$ air temperatures before and after each breakpoint and the corretion factors for those months where the confidence intervals overlap are shown in Table 1.

\section{TCD}

9, 5327-5371, 2015

A new spatially and temporally variable sigma parameter in degree-day melt

A. E. Jowett et al.

Title Page

Abstract

Introduction

Conclusions

References

Tables

Figures

14

$>1$

4

Back

Close

Full Screen / Esc

Printer-friendly Version

Interactive Discussion 

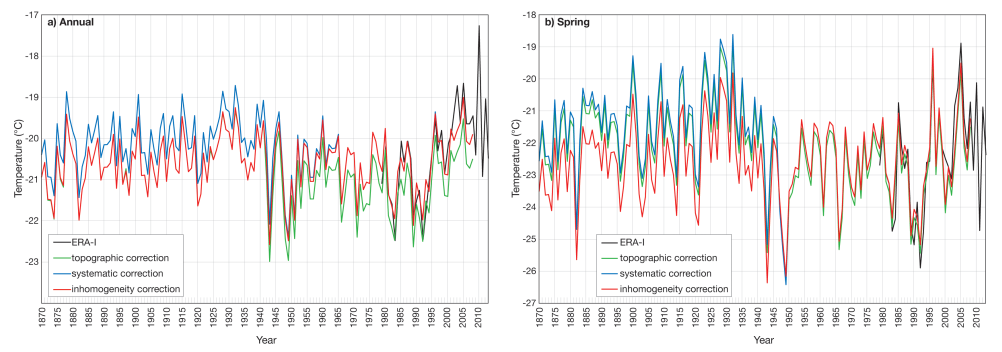

\section{TCD}

9, 5327-5371, 2015

A new spatially and temporally variable sigma parameter in degree-day melt

A. E. Jowett et al.

Title Page

Abstract

Introduction
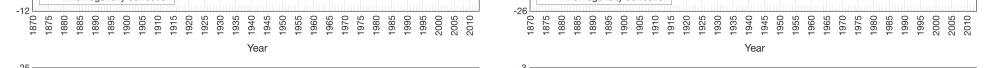

Conclusions

References
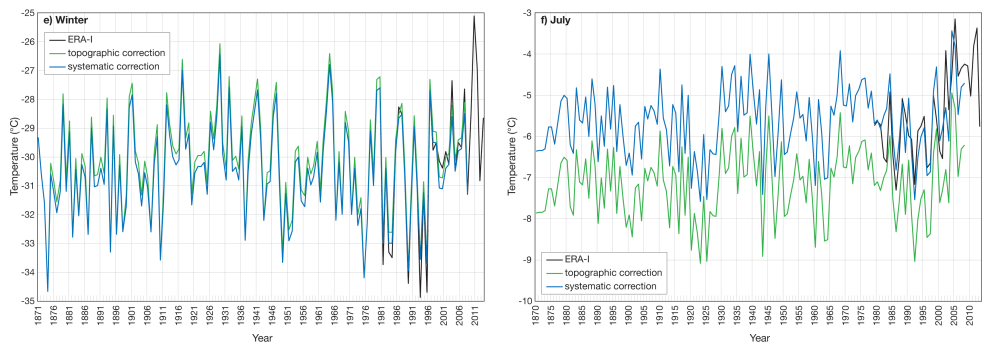

Tables

Figures

14

DI

4

Back

$>$

Close

Full Screen / Esc

Printer-friendly Version

Interactive Discussion 


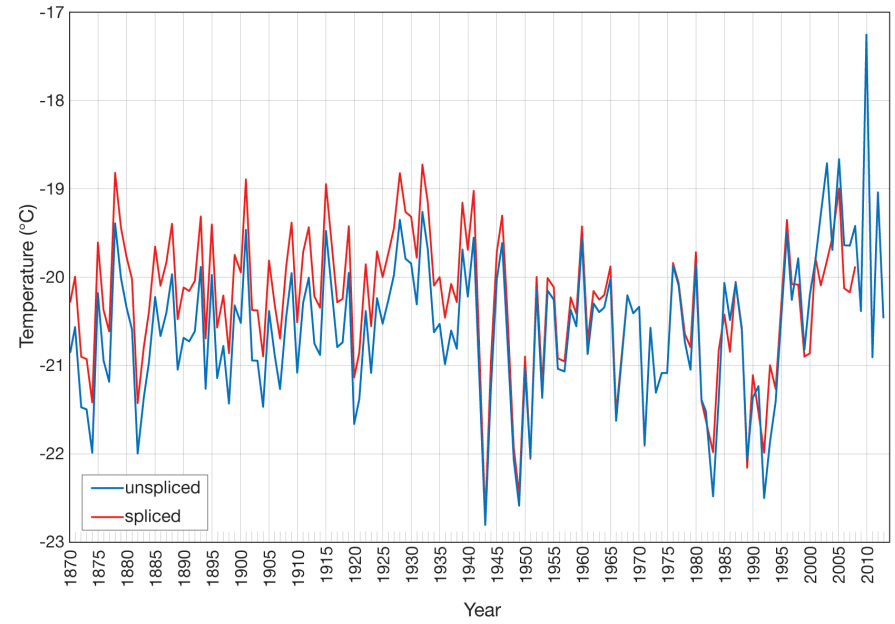

Figure 4. Ice sheet average annual spliced temperature series (blue line) calculated from 20CR (1870-1978) incorporating scaling to ERA-I and breakpoint correction factors and ERA-I (1979-2013), compared to the unspliced 20CR downscaled, corrected for the effect of orography and scaled to ERA-I (red line), highlighting the differences between 20CR and ERA-I for the overlap period.
TCD

9, 5327-5371, 2015

A new spatially and temporally variable sigma parameter in degree-day melt

A. E. Jowett et al.

\section{Title Page}

14

$\Delta$ I

4

Back

Close

Full Screen / Esc

Printer-friendly Version

Interactive Discussion 


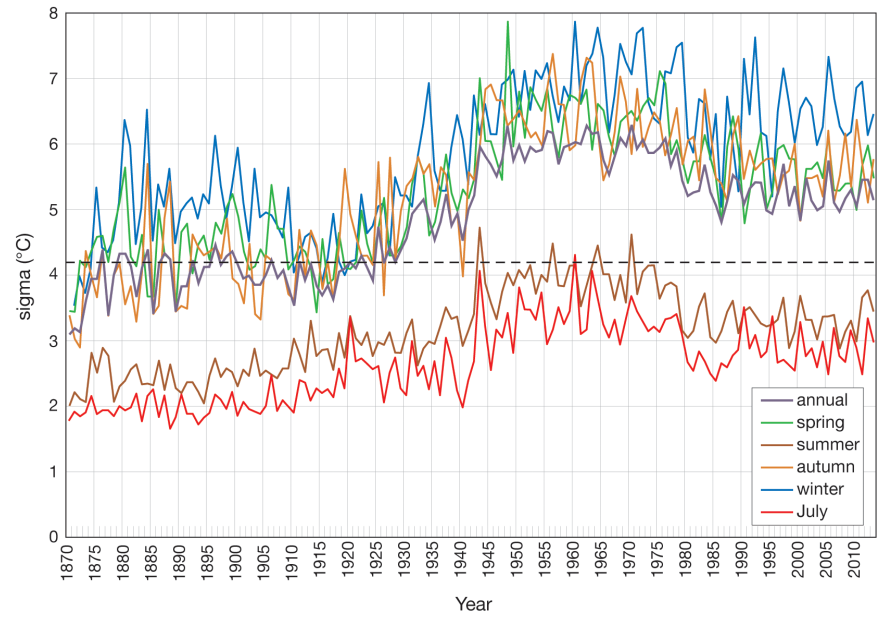

Figure 5. Annual, seasonal and July ice sheet average $\sigma$ from 1870-2013 calculated from spliced, fully corrected 20CR (1870-1978) and ERA-I (1979-2013) $2 \mathrm{~m}$ air temperatures, illustrating inter-annual fluctuations in $\sigma$. The seasonal series are calculated by averaging the monthly $\sigma$ series. The constant $\sigma$ value of $4.2^{\circ} \mathrm{C}$ is also marked (black dashed line) for direct comparison to the new parameter.

\section{TCD}

9, 5327-5371, 2015

A new spatially and temporally variable sigma parameter in degree-day melt

A. E. Jowett et al.

Title Page

Abstract

Introduction

Conclusions

References

Tables

Figures

14

DI

Back

Close

Full Screen / Esc

Printer-friendly Version

Interactive Discussion 

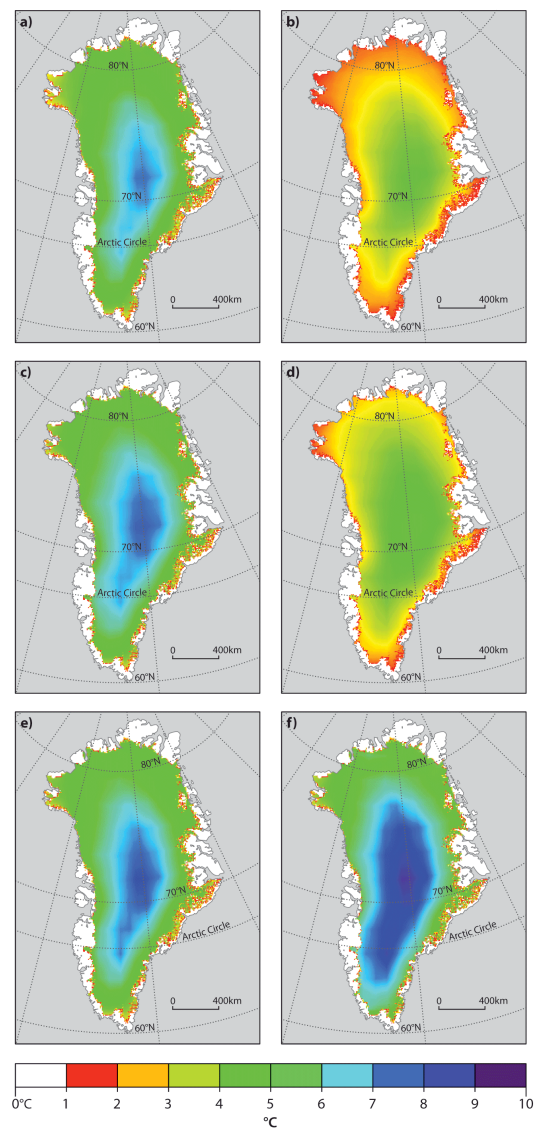

Figure 6. (a) Annual, (b) July, (c) spring, (d) summer, (e) autumn and (f) winter time averaged spatial plots of $\sigma$ from 1870-2013 inclusive calculated from monthly $2 \mathrm{~m}$ air temperatures that have been downscaled, corrected, scaled and corrected for breakpoints.

\section{TCD}

\section{9, 5327-5371, 2015}

A new spatially and temporally variable sigma parameter in degree-day melt

A. E. Jowett et al.

Title Page

Abstract

Introduction

Conclusions

References

Tables

Figures

14

4

Back

Close

Full Screen / Esc

Printer-friendly Version

Interactive Discussion 


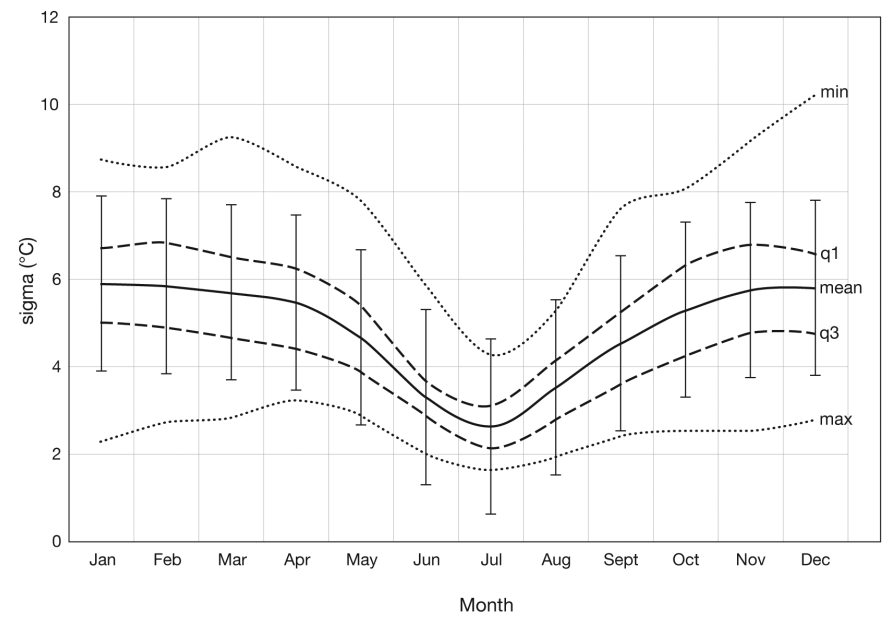

A new spatially and temporally variable sigma parameter in degree-day melt

A. E. Jowett et al.

Title Page

Abstract

Introduction

Conclusions

References

Tables

Figures

Figure 7. Mean $\sigma$ for each month (solid line) calculated by averaging the monthly ice sheet averaged $\sigma$ series for 1870-2013 with standard error bars. Minimum and maximum $\sigma$ (dotted lines) show the largest and smallest ice sheet average $\sigma$ for each month. Dashed lines indicate the 25 and $75 \%$ quartiles of ice sheet average $\sigma$ for each month, showing where $50 \%$ of $\sigma$ values lie. The seasonal cycle in $\sigma$ and the spread of values about the mean is clear, along with how this changes over the course of the year.

14

4

Back

Full Screen / Esc

Printer-friendly Version

Interactive Discussion 


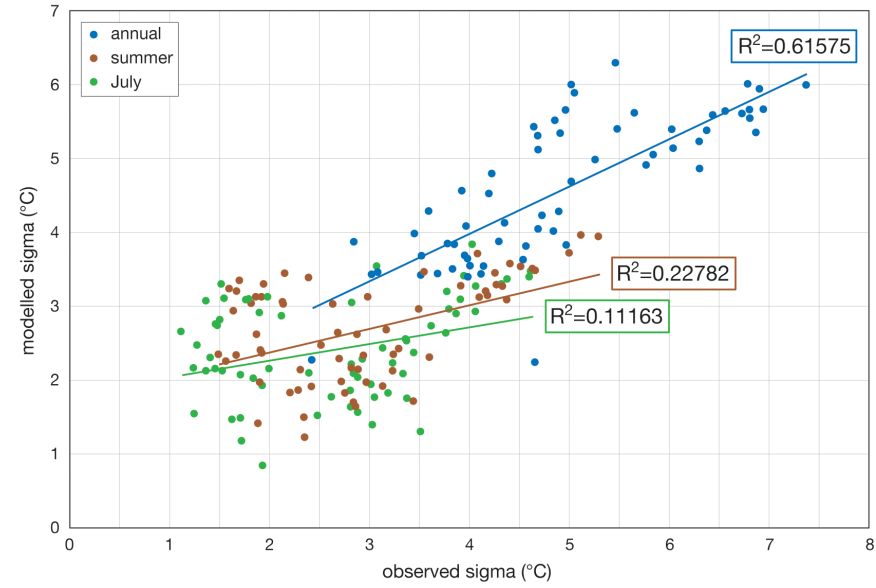

Figure 8. Correlation of annual summer and July $\sigma$ calculated from observed and re-analysis (model) $2 \mathrm{~m}$ air temperatures for DMI, GC-Net and PROMICE AWS, trend lines and their associated $R^{2}$ values. The validation covers the period from 1958-2012, however the period used for each station is different as the period of available measurements varies at each AWS. The total number of observations and relative contribution of each data set to the validation can be obtained from Tables 2, 3 and 4.

\section{TCD}

$9,5327-5371,2015$

A new spatially and temporally variable sigma parameter in degree-day melt

A. E. Jowett et al.

\section{Title Page}

14

$\Delta$ I

4

Back

Close

\section{Full Screen / Esc}

Printer-friendly Version

Interactive Discussion 


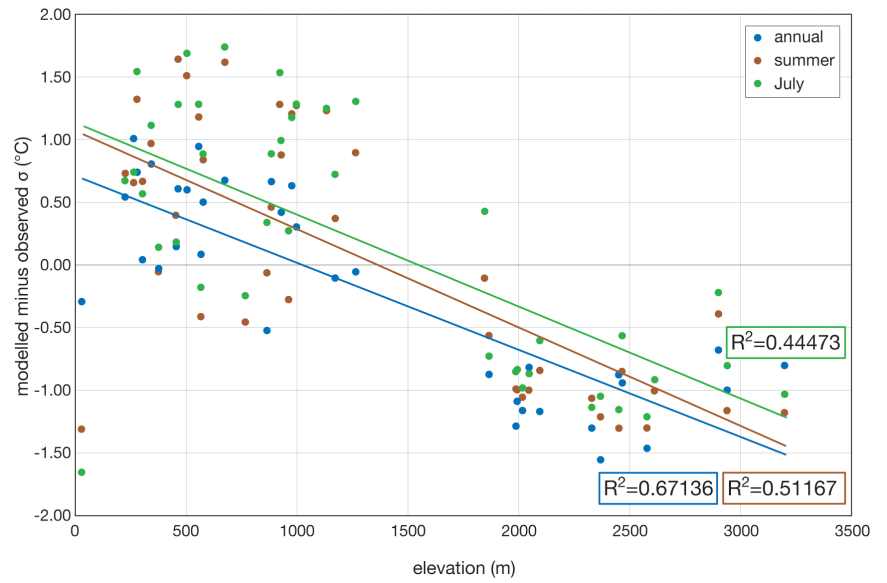

Figure 9. Annual, summer and July difference between modelled and observed $\sigma$ correlated against elevation, with trend lines and corresponding $R^{2}$ values. The ELA is taken to be around $1500 \mathrm{~m}$ where there is a systematic shift in the sign of the bias. Where there is a positive difference this indicates the model parameter overestimates $\sigma$ and where the difference is negative, the model parameter is underestimating $\sigma$ compared to the observations.
TCD

$9,5327-5371,2015$

A new spatially and temporally variable sigma parameter in degree-day melt

A. E. Jowett et al.

\section{Title Page}

Abstract

Introduction

Conclusions

References

Tables

Figures

14

4

Back

Close

Printer-friendly Version

Interactive Discussion 


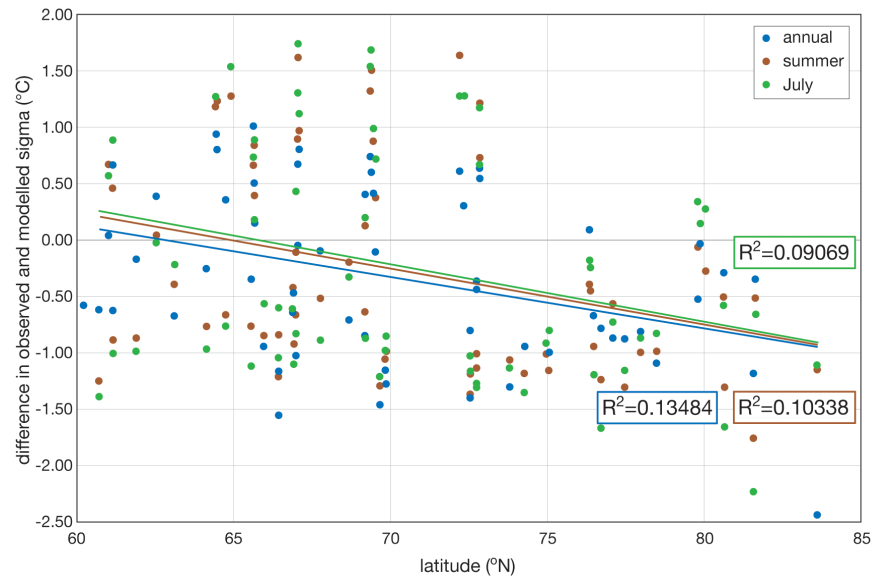

Figure 10. Correlation of the annual, summer and July difference in observed and modelled $\sigma$ against latitude with trend lines and corresponding $R^{2}$ values. The latitude is displayed in decimal degrees to 3 d.p. owing to the latitude of the AWS used in validation.
TCD

$9,5327-5371,2015$

A new spatially and temporally variable sigma parameter in degree-day melt

A. E. Jowett et al.

\section{Title Page}

Abstract

Introduction

Conclusions

References

Tables

Figures

14

Back

Close

Full Screen / Esc

Printer-friendly Version

Interactive Discussion 

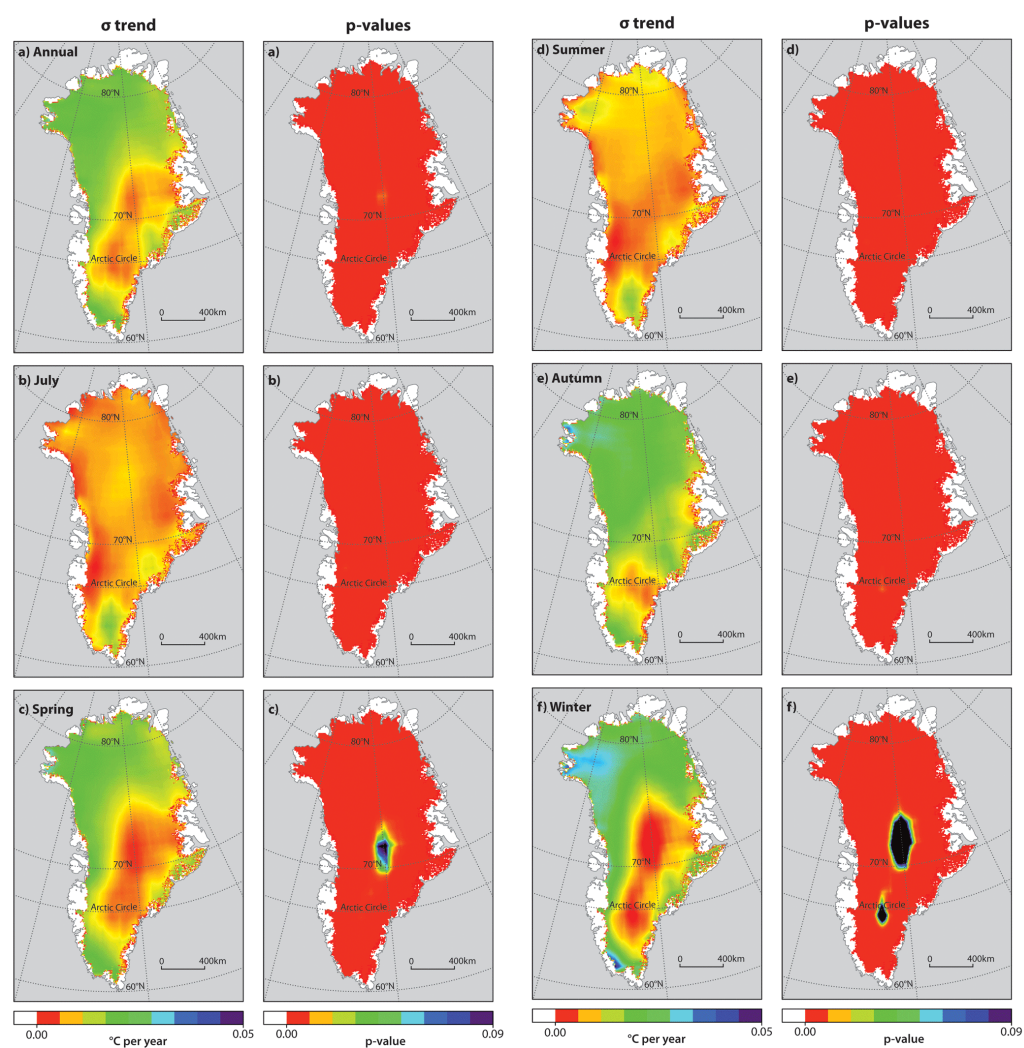

Figure 11. The left hand plots show the rate of change in $\sigma$ per year from 1870-2013 ( $\sigma$ trend) for each pixel on the ice sheet at the (a) annual, (b) July, (c) spring, (d) summer, (e) autumn and (f) winter scales. The right hand plots show the corresponding statistical significance ( $p$ values) to indicate the statistical significance of this rate of change. Values of 0.05 or less (red to green) are statistically significant at the $95 \%$ level.

\section{TCD}

\section{9, 5327-5371, 2015}

A new spatially and temporally variable sigma parameter in degree-day melt

\section{A. E. Jowett et al.}

Title Page

Abstract

Introduction

Conclusions

References

Tables

Figures

I4

$<$

Back

Close

Full Screen / Esc

Printer-friendly Version

Interactive Discussion 

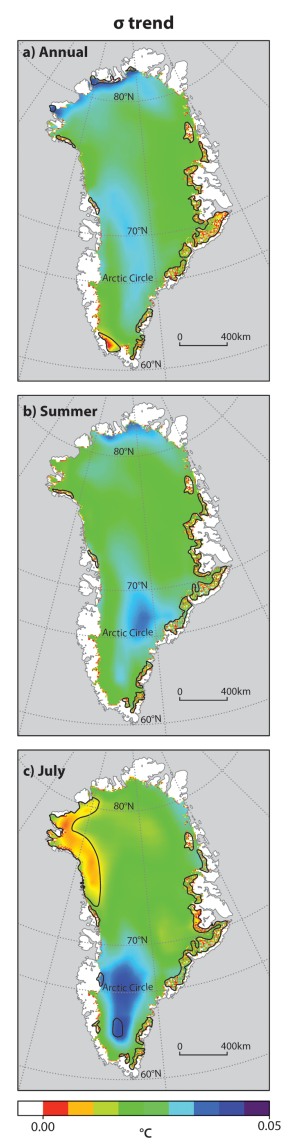

A new spatially and temporally variable sigma parameter in degree-day melt

A. E. Jowett et al.

Title Page

Figure 12. (a) Annual, (b) summer and (c) July sigma trend for the shorter time period 19902013. This captures the period of recent change across the GrIS. The areas outlined in black indicate the regions of the ice sheet where these trends are statistically significant at the $95 \%$ level.

14

4

Back

Close

Printer-friendly Version

Interactive Discussion 


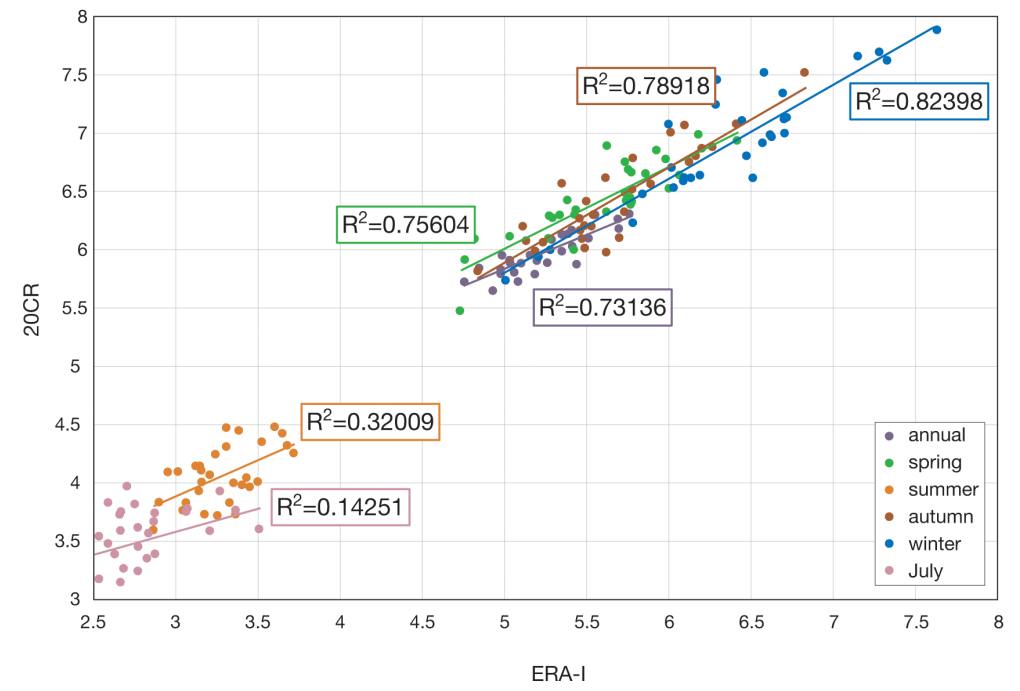

A new spatially and temporally variable sigma parameter in degree-day melt

A. E. Jowett et al.

Title Page

Abstract

Introduction

Conclusions

References

Tables

Figures

14

\section{DI}

4

Back

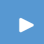

Figure 13. Correlation of ice sheet and time averaged $\sigma$ calculated from ERA-I and 20CR for the overlap period 1979-2008. The trend lines and corresponding correlation coefficients are displayed for the four seasons, annual and July periods.

Printer-friendly Version

Interactive Discussion 

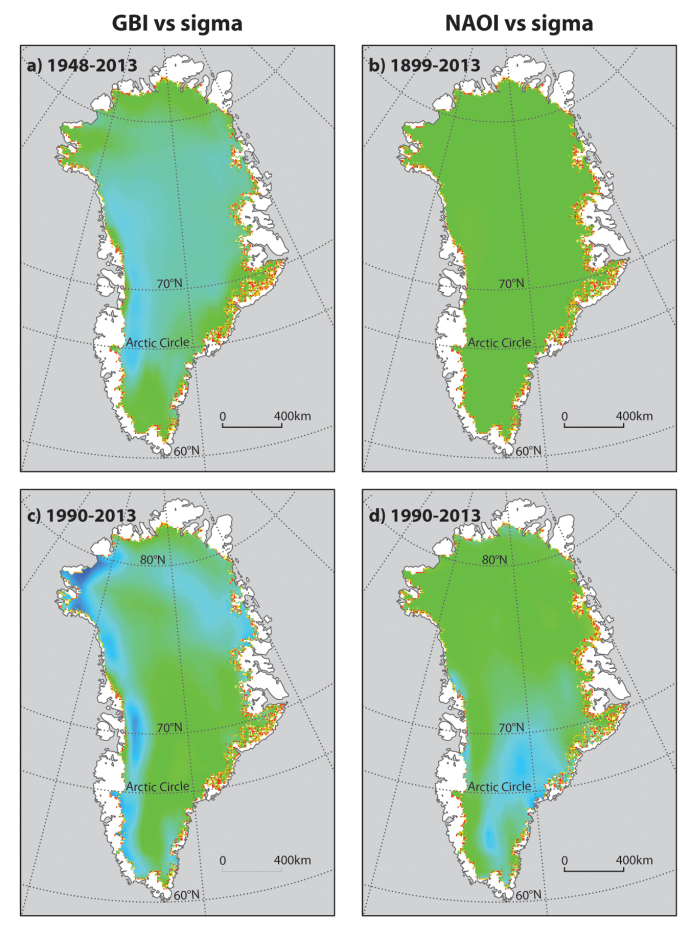

Correlation coefficient

\section{TCD}

\section{9, 5327-5371, 2015}

A new spatially and temporally variable sigma parameter in degree-day melt

A. E. Jowett et al.

\section{Title Page}

Abstract

Introduction

Conclusions

References

Tables

Figures

I4

4

Back

Close

Figure 14. Correlation coefficients of summer NAOI vs. $\sigma$ from (a) 1899-2013 (b) 1990-2013, and summer GBI vs. $\sigma$ from (c) 1948-2013 and (d) 1990-2013.

Printer-friendly Version

Interactive Discussion 